Discussion Paper No. 05-68

\title{
The Targeted Negative Income Tax (TNIT) in Germany: \\ Evidence from a Quasi Experiment
}

Alexander Spermann and Harald Strotmann

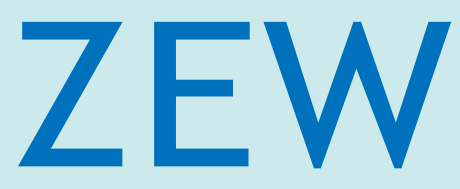

Zentrum für Europäische Wirtschaftsforschung $\mathrm{GmbH}$

Centre for European

Economic Research 
Discussion Paper No. 05-68

\title{
The Targeted Negative Income Tax (TNIT) in Germany: \\ Evidence from a Quasi Experiment
}

\author{
Alexander Spermann and Harald Strotmann
}

Download this ZEW Discussion Paper from our ftp server:

ftp://ftp.zew.de/pub/zew-docs/dp/dp0568.pdf

Die Discussion Papers dienen einer möglichst schnellen Verbreitung von neueren Forschungsarbeiten des ZEW. Die Beiträge liegen in alleiniger Verantwortung der Autoren und stellen nicht notwendigerweise die Meinung des ZEW dar.

Discussion Papers are intended to make results of ZEW research promptly available to other economists in order to encourage discussion and suggestions for revisions. The authors are solely responsible for the contents which do not necessarily represent the opinion of the ZEW. 


\section{Non-technical Summary}

Financial incentive schemes and social experiments are standard in the U.S. Mixed experimental evidence on Negative Income Tax (NIT)schemes in the 1960s and 1970s resulted in the implementation of in-work benefits such as the Earned Income Tax Credit. In the 1990s, in-work benefits were expanded in the U.S. and the U.K. and new incentive schemes such as the Self Sufficiency Project (SSP) in Canada were tested in practice by social experiments.

In Germany, financial incentive schemes attracted very little attention prior to the 1990s. Benefit reduction rates for (long-term) unemployed were very high and this created a poverty trap. Furthermore, state administrators faced huge caseloads. Therefore, it was rational from their perspective to focus on correct payment of benefits. Long-term unemployed people received means-tested unemployment aid and/or public assistance within a very complicated institutional setting which was simplified only recently by merging these two systems in 2005 ("Hartz IV" law).

Furthermore, evaluation culture in Germany lagged behind international standards in the 1990s. Typically, new programs were introduced and case numbers counted using "evaluators" rather than solving a fundamental evaluation problem. Non experimental studies were rarely feasible for researchers due to data constraints and social experiments with randomized control groups were rejected for reasons of equity.

We report empirical evidence from an innovative financial incentive scheme called "Targeted Negative Income Tax (TNIT)" which is a time-restricted employee subsidy for means-tested welfare recipients and was especially designed for the German tax-and-transfer system by Spermann (1996). This program was tested by field experiments with program and control groups which were conducted between 1999 and 2002. Some field experiments were designed - for the first time in Germany - as social experiments with randomized control groups.

In this paper, we focus on a quasi experiment with TNIT in Mannheim (site randomization within the same local labour market) where a unique data set on welfare recipients in Mannheim was accessible to a microeconometric study. We find an average treatment effect of TNIT on the participation probability between 6.6 and 6.8 percentage points.

Since January 1st, 2005, TNIT may be offered to more than 4 million means-tested long-term unemployed who receive "Arbeitslosengeld II". 


\title{
The Targeted Negative Income Tax (TNIT) in Germany: Evidence from a Quasi experiment
}

\author{
Alexander Spermann* and Harald Strotmann ${ }^{\dagger}$
}

October 17, 2005

\begin{abstract}
*Centre for European Economic Research (ZEW), Mannheim
University of Freiburg

$\dagger$ Institute for Applied Economic Research (IAW), Tübingen
\end{abstract}

\begin{abstract}
We report empirical evidence from the first field experiments to be conducted in Germany with program and control groups between 1999 and 2002. The evaluated program called "Targeted Negative Income Tax (TNIT)" is a time-restricted employee subsidy for means-tested welfare recipients. We focus on a unique data set on welfare recipients in Mannheim and estimate the treatment effect of TNIT on participation probability. The average treatment effect is significant and lies between 6.6 and 6.8 percentage points. Since January 1st, 2005, TNIT can be offered to all means-tested long-term unemployed people in Germany by public case managers.
\end{abstract}

Keywords: Field experiments, Labor Market Reform, Negative Income Tax, employee subsidy, long-term unemployment

\section{JEL-classification: C 93, I 38, J 22}

${ }^{*}$ Corresponding author: Alexander Spermann, Centre for European Economic Research (ZEW), PO Box 103443, D-68034 Mannheim, e-mail: spermann@zew.de

${ }^{\dagger}$ Institute for Applied Economic Research (IAW), Ob dem Himmelreich 1, D-72074 Tübingen, e-mail: harald.strotmann@iaw.edu 


\title{
The Targeted Negative Income Tax (TNIT) in Germany: Evidence from a Quasi experiment
}

\author{
Alexander Spermann (ZEW and University of Freiburg) and Harald Strotmann (IAW $)^{1}$
}

\section{Introduction}

In 2004, Germany managed its "most important labor-market reform since the war" (Economist, January 1st, 2005). The core of this reform is the merger of two tax-financed transfer schemes - unemployment aid and public assistance to able-bodied welfare recipients into one meanstested transfer, the so-called unemployment benefit II. Since 2005, about 2.5 million mostly long-term unemployed people have been receiving this transfer. Furthermore, case managers may offer them a so-called Targeted Negative Income Tax (TNIT=Einstiegsgeld) which is a time-restricted German version of an in-work benefit that makes work pay within the existing transfer system. In-work benefits are well-known e.g. as Working Tax Credit/Child Tax Credit in U.K. or as Earned Income Tax Credit in the U.S. and are designed to create financial incentives outside the traditional welfare system ${ }^{2}$.

TNIT tries to circumvent the well-known poverty trap in the German tax-and-transfer system for a certain time period. TNIT was developed by Spermann $(1996,2001)$ as a part of his habilitation thesis. Although the name itself may be misleading, TNIT does make use of the financial incentives associated with a Negative Income Tax (NIT) scheme. However, it avoids the disadvantages such as disincentives for those already in employment, by imposing two restrictions. First, the NIT-scheme is exclusively targeted on means-tested (long-term) unemployed. Second, the NIT-scheme is time-restricted. These two features minimize dead-

\footnotetext{
${ }^{1}$ We are grateful to Bernd Fitzenberger, Philip Robins, Gerd Ronning and Jeff Smith for scientific consultancy during the social experiments' set-up as well as Sabine Dann, Andrea Kirchmann and Jürgen Volkert from the IAW evaluation team for their support over the years. Furthermore, we thank Miguel Gouveia, Shannon Seitz as well as participants of the IIPF-Congress 2004 in Milan, the EALE-Conference 2004 in Lisbon, the Conference on Evaluation Research 2004 at ZEW Mannheim, the Royal Economic Society Meeting 2005 in Nottingham for very useful comments on an earlier draft. This draft was presented at the European Economic Association (EEA) Meeting 2005 in Amsterdam and the Annual Meeting of the Verein für Socialpolitik 2005 in Bonn. The usual disclaimer applies.

${ }^{2}$ See Moffitt 2003 and Crawford/Shaw 2004 for a detailed description of the U.S. and U.K. benefit system, respectively, as well as OECD 1997, 2003 for international comparisons.
} 
weight, displacement and entry effects ${ }^{3}$. TNIT highlights - like all in-work benefits - financial incentives for welfare recipients embedded in the legal obligation to work.

This approach represents a paradigm change - at least in Germany. In the 1990s, municipalities relied on the stick of benefit cuts rather than on the carrot of incentives. As a result, very few cities and counties were interested in participating in field experiments with an incentive-scheme ${ }^{4}$. Furthermore, social experiments with randomized control groups were completely new for local administrators in Germany and they were consequently very reluctant to engage in such experiments ${ }^{5}$. Finally, field experiments with the so-called Targeted Negative Income Tax (TNIT), a time restricted employee subsidy for the long-term unemployed, were conducted in 16 cities and counties between 1999 and 2002 in Germany. Seven of these involved social experiments with randomized control groups (Freiburg, Fulda, County and City of Kassel, Odenwald, Offenbach, Tuebingen) carried out for the first time in Germany. Two field experiments were conducted as so-called quasi experiments with the special feature of a control group in the same local labor market (Frankfurt and Mannheim), six field experiments were conducted without control groups (see Table A1 and A2).

To avoid misunderstandings with respect to the terminology, some definitions have to be clarified. Experimental methods in labor economics are rather new tools. These methods produce experimental data: field data is derived from field experiments, laboratory data from lab experiments (see Falk/Fehr 2003 and Bertrand/Mullainathan 2004). Social experiments are defined as field experiments with random assignment in the literature (see Greenberg/Shroder 2004, Greenberg/Shroder/Onstott 1999, Heckman/Smith 1995, Orr 1999). Quasi experiments are defined by Greenberg/Shroder (2004) as site randomized field experiments in which some sites function as the program group and comparable sites as the control group. Unfortunately, some authors use the term quasi experiment as a synomym for natural experiments (e.g. Winter-Ebmer 1998), and this may confuse the reader. However, the natural experiment approach considers the policy reform itself as an experiment and is often labelled "difference-in-differences" (Blundell and Costa Dias 2002).

\footnotetext{
${ }^{3}$ See Jerger/Spermann 1997, 2003 and Spermann 1999 for a detailed discussion and a comparison to EITC and Dennis Snower's Benefit-Transfer-Programme.

${ }^{4}$ In Bavaria, state administrators even offered funding for field experiments with TNIT but no municipality was interested in experiments with financial incentives.

${ }^{5}$ Social experiments are still rare in Europe (see Heckman/Lalonde/Smith 1999 and Greenberg/Shroder 2004). Recently, van den Berg/van der Klaauw (2001) report results from a Dutch and Rosholm/Skipper (2003) from a Danish social experiment.
} 
This paper focuses on the quasi experiment carried out in the city of Mannheim with program and control groups in the same local labor market. Mannheim was the only site where the number of observations was sufficient for a microeconometric analysis and data quality satisfactory for the purposes of a microeconometric analysis. The sample consists of 914 welfare recipients. For several reasons, no other sites - including the social experiment sites - were amenable to an econometric analysis. This was partly due to the fact that, owing to the reluctance of local administrators, the treatment group did not actually receive any treatment at all. Welfare recipients merely received a letter in which they were informed about the program, even though administrators realised that only very few of the recipients would understand what the program entailed. Second, administrative data was not reliable, e.g. we found highly significant positive treatment effects based on administrative data for the social experiment site Fulda where the program group really received the program, but this result surprisingly contradicted the numbers calculated on the same data base by administrators. Third, the number of observations was simply too small for some sites (see Table A1 and A2).

The TNIT experiment in Germany could be called the "small brother" of the Canadian SelfSufficiency Project SSP experiment. SSP was conducted as a huge social experiment during an 8-year period of demonstration in the 1990s and involved around 9,000 single parents who were monitored for five years after joining the experiments. ${ }^{6}$

The remainder of the paper is organized as follows. Section 2 describes the 'poverty trap' in the German public assistance system which causes disincentive effects for unemployed and welfare recipients. Section 3 describes TNIT from the point of view of public assistance recipients and the public assistance authority and compares it with the Canadian SSP. Section 4 describes implementation, evaluation design and data. Section 5 states the fundamental evaluation problem, defines treatment and outcome of interest and discusses identification. Section 6 reports Probit and Tobit estimates of the probability to be employed in the private sector if welfare participants are in the program group and discusses the results. Section 7 concludes and sets out an agenda how to evaluate TNIT from 2005 onwards.

\footnotetext{
${ }^{6}$ See Blank et al. 2000, Card 2000 and Michalopoulos et al. 2005 for surveys.
} 


\section{The poverty trap in the German public assistance system}

A common feature of most European transfer systems is the so-called poverty trap in which a person's almost entire earned income is withdrawn above very low earnings disregards (OECD 1997, 2003). Poverty traps in Germany are highly relevant for all means-tested unemployed people and are very complicated in detail. Up to 2004, poverty traps occurred within the federal unemployment aid system and within the public assistance system. In 2005 unemployment aid was merged with public assistance but the poverty trap remained more or less unchanged except for the introduction of a time-restricted TNIT subject to case managers discretion. It is a special feature of the German benefit system that the public assistance poverty trap differs between states, cities and counties as well as household types. In this paper, we provide a case study for the city of Mannheim in the state of Baden-Wuerttemberg in 2000. Our description of the status quo consequently refers to the relevant rules for the field experiment at that period of time (see Adema/Gray/Kahl 2003 for a detailed description for Germany).

The public assistance need standard is dependent on family size, housing costs and living costs. The need standard is higher for larger families and in urban areas. In line with common practice across OECD countries, the public assistance means test considers assets and income of the applicant as well as of other household members. But only very few countries take the income of parents and adult children as well as separated or divorces spouses into account. In an international context, the German public assistance means-test is thus highly restrictive.

The poverty trap in Mannheim is associated with a benefit reduction rate (BRR) of between $75 \%$ and $100 \%$ above a household-type specific earnings disregard. Note, that status quo break-even gross income, i.e. the gross income you need to come off welfare, depends on household types and varies enormously between 1,718 and 5,105 deutschmarks for single people and families with two and more children, respectively (see Table A3 in the Appendix).

The poverty trap for welfare recipients in Mannheim in 2000 is shown in a numerical example in Table A4. It may be illustrated with some simplifications in a well-known monthly incomebefore-transfer/income-after-transfer framework in Figure 1. High benefit reduction rates BRR are economically identical with high marginal tax rates $t$ that reduce the welfare 
recipients' net wage thereby making the income after transfer line flat. Note, that the $45^{\circ}$ line constitutes a world without taxes and transfers and net income line below the $45^{\circ}$-line is relevant for non-transfer recipients.

Figure 1: The poverty trap in Germany - Single person in the City of Mannheim in 2000

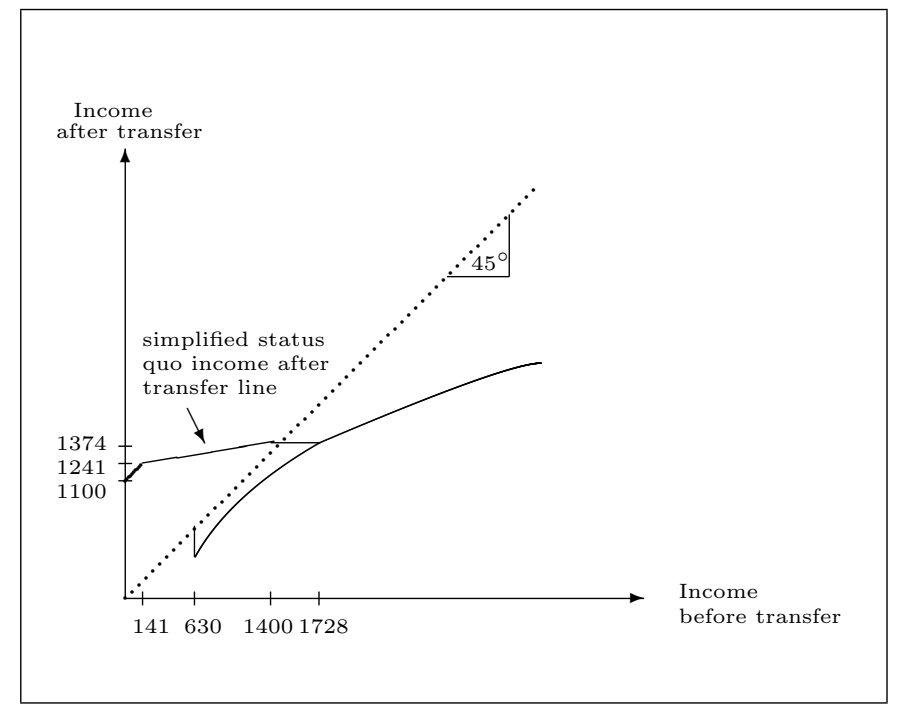

Starting from an average need standard of 1,100 deutschmarks, single people face an earnings disregard of 141 deutschmarks and a BRR of $85 \%$ up to a net income of 1,115 deutschmarks. Above this threshold, the BRR rises to $100 \%$ up to the break-even net income of 1,374 deutschmarks. The same pattern - earnings disregard, high BRR, 100\% BRR up to the break-even net income - can be observed for all household types ${ }^{7}$. Note, that the notch of the status quo net income line below the $45^{\circ}$-line stems from an average social contributions rate of $20 \%$ on the gross income above 630 deutschmarks. Non-linearity comes from the tax system with increasing marginal rates above the minimum existence of about 1,000 deutschmarks for a single person.

\footnotetext{
${ }^{7}$ In fact, as the reader may notice in Table A4, the disposable income under the status quo even decreases if singles earn a little bit above 630 deutschmarks. This is due to the BRR's base which refers to the net income rather than to the gross income. This very special feature is not captured in figure 2 .
} 


\section{How TNIT worked in the city of Mannheim}

TNIT has three main features. First, the target group are means-tested (long-term) unemployed people. Second, TNIT is paid as an employee subsidy to welfare recipients. The employee subsidy is implemented as a low benefit-reduction-rate on net earnings in the private labor market or - equivalently - as an earnings supplement, i.e. as a top-up to regular public assistance. Third, TNIT is time-restricted, with the relevant time restriction varying between household types.

In Mannheim, local administrators chose a special variant of TNIT which they believed best matched local conditions. Targeting referred to the means-test rather than the duration of unemployed. The target group consequently consists of able-bodied welfare recipients such as long-term unemployed people on unemployment benefits for one year who have passed the means-test. A special feature of the German system in 2000 was that those on unemployment benefits who had already passed a means-test set by the Federal Employment Services could also receive public assistance if they passed the tougher means-test for public assistance at the municipality level. Second, local administrators chose a 50\% earnings supplement on gross income up to a maximum of 1,500 deutschmarks. Administrators explicitly followed a "Keep it simple" (KIS) strategy with regard to the low-qualified long-term unemployed on whom they had previously tried the stick treatment. Case Managers typically explained TNIT in the following way: "We will finance your new Mercedes Smart by giving you 1,500 deutschmarks a month for one year if you take a job on a monthly gross income of 3,000 deutschmarks". Third, TNIT was time-restricted for one year. However, employment periods could be accumulated up to one year bearing in mind that the low-qualified long-term unemployment often only find short-term jobs.

\section{Incentives and potential disincentives of TNIT}

Figure 2 provides a simplified illustration of the TNIT-incentive structure in a monthly income before transfer/income after transfer diagram for a single person. The TNIT program parameter in Mannheim in 2000 was the need standard or benefit level G amounting to 1,100 deutschmarks for a single person and BRR or t which is exogenously set at $50 \%$. 
Figure 2: The Targeted Negative Income Tax (TNIT) in Mannheim 2000

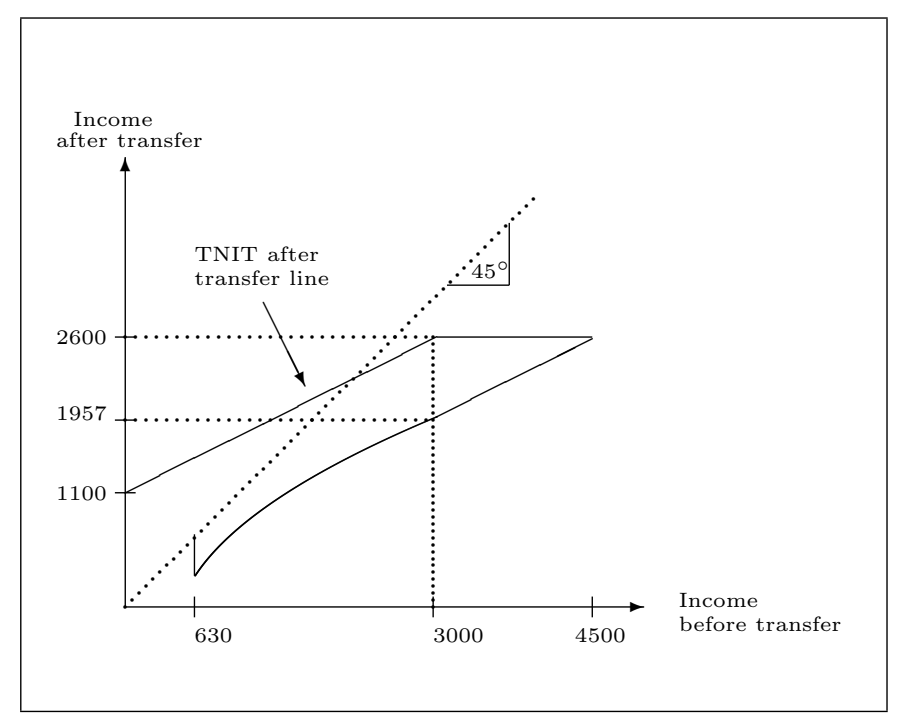

Source: Calculations by local administrators in Mannheim according to tax and social contribution laws in 2000

An illustrative example for the maximum earnings supplement: A single welfare recipient has a disposable net income of 2,600 deutschmarks for one year if he earns a gross income of 3,000 Deutschmarks a month. In this case he could improve his disposable net income by 643 deutschmarks (earnings supplement=TNIT) compared with the status quo (see Table A4), because he would only earn a net income of 1,957 deutschmarks without an earnings supplement. ${ }^{8}$ After one year, he looses the earnings supplement, but in this case he would have left welfare. Note once again, that this is only the case for single people and couples without children. All other household types would remain on welfare with small sums even if they stayed in their 3,000 deutschmarks job. Note, that all other cities and counties chose more restrictive TNIT variants where welfare recipients did not receive earning supplements if they earned a net income above the break-even point. Therefore, the Mannheim TNIT variant was the most attractive financial incentive scheme in Germany.

Figure 2 reveals five potential disincentives of TNIT:

(1) The TNIT-after transfer line simply shifted the poverty trap to a higher income level. All other sites chose a TNIT variant with a time-restricted notch at the household specific

\footnotetext{
${ }^{8}$ As the reader may notice in Table A4, TNIT takes account of the earnings disregard so that the TNIT after transfer line is at least as favorable to welfare recipients than the status quo. However, this feature is not captured in the figure for simplicity.
} 
break-even point. Although these are uncomfortable features of TNIT at first glance and from a static point of view, they turned out to be negligible in practice for two reasons: (i) Welfare recipients only have a very low probability of getting well-paid jobs due to their low or depreciated human capital and in most cases such higher gross incomes are not within this group's range of opportunities. (ii) Most welfare recipients, especially those with a somewhat higher probability of getting a better paid job, do not like living on welfare: public assistance payments are a bad in their utility function and recipients thus prefer to come off welfare rather than stay on the rolls with a well-paid job. ${ }^{9}$

(2) The Mannheim TNIT version is associated with a somewhat higher break-even level than under the status quo for single people, single mothers with one child and couples without children due to the low BRR up to a gross income of 3,000 deutschmarks. But the status quo break-even gross income remains unchanged for all other household types. Note that most household types with children do not come off welfare even if they earn a gross income of 3,000 deutschmarks. Therefore, the Mannheim TNIT variant is still well protected against windfall beneficiaries for most household types.

(3) The time restriction is associated with a loss of income after transfer because welfare recipients drop down to the lower status quo net income line after the employee subsidy has run out. However, TNIT counts on human capital investment as well as wage progression within the time limit (Blundell 2002).

(4) Non-welfare recipients have a lower net income than TNIT recipients for the same gross income for a certain time period. This may enhance the incentive to enter welfare (new applicant effect). However, this theoretical argument is negligible for two reasons: (i) incumbent workers with a minimum employment history receive in general unemployment benefits for 12 months; (ii) even if incumbent workers do not receive unemployment benefit for some reasons they have to pass the means-test. ${ }^{10}$

(5) A delayed exit effect could be associated with TNIT because the target group are meanstested unemployed. Once again, the hurdle means-test is the argument against the large-scale relevance of this kind of entry effect but it could be true for unemployed with a very high probability to pass the means-tested.

\footnotetext{
${ }^{9}$ These arguments are based on local administrators experiences.

${ }^{10}$ In summer 2004, unemployment aid recipients demonstrated against Hartz IV not only due to the lower benefit level associated with unemployment benefit but also due to the tougher means-test.
} 
Overall, TNIT is associated with high financial incentives at the relevant gross income levels for the long-term unemployed. Nevertheless, long-term unemployed people who get a higher paid job beyond the break-even point leave welfare by construction of the TNIT-tariff although the Mannheim TNIT variant removes the status quo break-even to somewhat higher level for some household types which turned out to be negligible in practice.

\section{Incentives for public assistance authorities}

The main incentive for local policymakers to introduce TNIT was to try the carrot of a financial incentive scheme as a complement to the stick of benefit cutting in a world of legal obligation to work. One attractive feature of TNIT is that the system costs relatively little to launch. First, TNIT is associated with very low administrative costs. This is mainly because it is an in-work benefit within the transfer system. Unlike the former WFTC in U.K or EITC in the U.S. or SSP in Canada, TNIT is designed within the "system of last resort" (public assistance up to 2004, unemployment benefit II since 2005) thereby integrating all other available benefits in Germany.

To make this crucial point clearer: TNIT takes into account all other transfer programs of the German benefit system, so that the $50 \%$-BRR is the effective BRR. However, it is well known from the literature that the effective BRR for welfare recipients can differ heavily from in-work benefit schemes designed outside the system. Two examples: Dickert/Houser/Scholz (1995) find effective BRR for the U.S. welfare recipients of up to $175 \%$ in the phase-out region of EITC. Duncan/Giles (1996) find effective BRR for U.K. welfare recipients up to $80 \%$ in spite of what at first appears to be a financially attractive Family Credit - a feature that does not change substantially with Working Family Tax Credit (WFTC) but improved with the new U.K. tax credits (2004/2005) as Blundell and Hoynes (2003) point out.

The TNIT-saving mechanism is well-known to all economists familiar with NIT. It is obvious that a $50 \%$ BRR reduces fiscal expenditures by $50 \%$ of welfare recipients' income. However, this is only true if welfare recipients had not worked in the counterfactual situation. Therefore, evaluation of TNIT had to take into account the fundamental evaluation problem (see Section 5). Another saving mechanism is due to a special feature of German public assistance whereby welfare recipients not only receive public assistance based on their household type dependent need standard, their health expenditures are also covered. However, jobs in the private sector - including part-time jobs - are subject to health insurance and this immediately leads to fiscal savings for municipalities. 
Like the Canadian SSP, TNIT offers means-tested welfare recipients a time-restricted earnings supplement. The program rules differ in each case, however. These differences can be understood by considering the SSP system, as illustrated in the gross income/net income diagram shown in Figure 3 (Card (2000)). G is the benefit level for single mothers which is independent of family size under SSP. The SSP program parameter in New Brunswick in 1994 were equivalent to a welfare system with $G=\$ 1,250$ and a BRR of $50 \%$. Therefore, welfare recipients net wage under SSP is $w(1-t)$ which is the slope of SSP's net income line. The exogenous program parameter $\mathrm{G}$ and $\mathrm{t}$ yield an endogenous break-even net income $Y^{*}$ of $2,500 \$$ which is the intersection of the SSP net income line and the $45^{\circ}$-degree line. ${ }^{11}$ Intuitively, welfare recipients receive $G$ plus a fraction $t$ of the difference between $G / t$ and $G$ as earnings supplement if they work at least 30 hours a week which is the full-time requirement h. Note, that the G-level under SSP is higher for most single mothers than the G-level in the Canadian IA system (see Blundell 2002).

Figure 3: The Canadian Self Sufficiency Project (SSP)

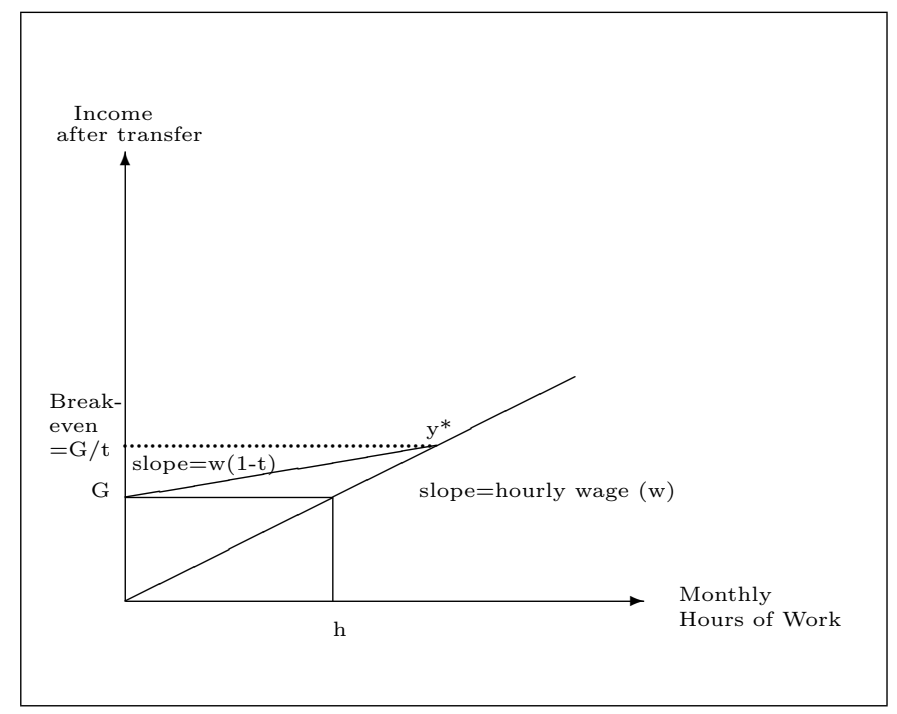

Source: Card 2000

A comparison of TNIT and SSP yields four main differences. First, TNIT is implemented as part of the German welfare system; SSP in contrast is not part of the Canadian Income Assistance (IA) system. Second, in the SSP-system G is a fixed base payment that is

\footnotetext{
${ }^{11}$ The formula for the break-even net income: $Y^{*}=G / t=1250 / 0.5=2500$.
} 
independent of family size, but higher than the IA level for most single mothers whereas in the TNIT system G is dependent on family size and varies by household type. Therefore, SSP is associated with higher financial incentives than TNIT due to fixed G on a high level. Third, TNIT differs from SSP with respect to targeting. TNIT is open to all household types, whereas SSP is restricted to single mothers. Fourth, TNIT is independent of hours worked but dependent on gross income.

\section{Implementation, Experimental Design and Data}

The legal basis for TNIT experiments in Germany was the waiver of $\S 18 / 5$ Federal Public Assistance Act. It was exclusively designed by policymakers in 1999 after having been informed about TNIT in previous years. On the basis of this waiver, the State Ministries of Social Affairs in Baden-Wuerttemberg and Hesse invited cities and counties with public assistance competence to participate in field experiments with TNIT. In most cases, sites were self selected on a "first come, first serve-basis" and only in few instances were sites selected by state administrators due to budget constraints. A total of 16 cities and counties participated in the experiment. Site selection was thus non-random. Some, if not all of the sites, reflect positive selection. Mannheim is one particular example of a positively selected site, and this is problematic as far as the external validity of our results is concerned. The funding State Ministries mandated the Tuebingen Institute for Applied Economic Research (IAW) with the monitoring and evaluation of the field experiments (see Dann et al. 2002a,b for final reports).

\section{Quasi experiment in Mannheim}

In 2000, Mannheim had the highest unemployment rate and the highest welfare recipient density in Baden-Wuerttemberg. Local policymakers and administrators in Mannheim mainly relied on the stick approach in the 1990s with respect to the long-term unemployed and were eager to implement TNIT as a carrot. Implementation was consequently successful: Target group and TNIT variant as well as information and communication strategies were discussed intensively with the evaluation team. However, evaluation design was a controversial issue. Municipality administrators could not accept randomized control groups due to equity considerations and fear of protests from well-organized welfare recipients. However, administrators did agree to site randomization within the city of Mannheim. Local administrators 
chose comparable districts within the city on the basis of socio-economic district information such as welfare recipient density and structure as well as subjective experience-based information. Finally, districts in the northern part of Mannheim were chosen as program districts, while others in the southern part of Mannheim were chosen as control districts. Program and control group welfare recipients are similar with respect to most observable characteristics according to t-tests. While the program was also offered in the centre (special districts), the control district (southern part of Mannheim) is only comparable with the program group which excludes special districts. The program and control districts are part of the same local labor market with small distances to potential employers and a well-organized public transport system. The target group was informed about the program by letter in December and in the following time period by their case managers during regular visits to the public assistance office. The local press were also informed several times about TNIT, and the program even made it on the front page story on one occasion.

A group of long-term unemployed people was informed about TNIT in December 1999. Local administrators also checked new eligibles each month and informed them about TNIT. The intake period for TNIT in the northern part of the city was between January 1st, 2000, and September 30th, 2001, but the evaluation period was restricted to 2000. The descriptive interim results produced by the program were more successful than local administrators had expected, and as of October 1st, 2001 TNIT has been implemented throughout Mannheim (see Dann et al. 2001).

Data

We use an informative administrative data set which was set up by public case managers in personal interviews according to the Federal Public Assistance Act. The evaluation team received anonymized microdata on welfare recipients compromising information on stock and new eligibles for the overall evaluation period. Unfortunately, we have not received any data on the employment history of households involved in the field experiment so far, despite out attempts to obtain such data from the Federal Employment Services. The data set was modified in a number of ways: People without a job but with an income of their own were dropped. Missing values for the income variable were replaced with zero for people without a job. People who were already employed in so-called 630 DM part-time jobs at the beginning of the experiment were dropped in order to sharpen the focus on participation decisions.

The data set does have one peculiar feature in that people with jobs paying wages above 
the household's break-even point do not turn up in the data set. This means that the most successful people as far as employment is concerned are not included in the data set. However, there are other potential the reasons apart from taking up new employment why people might come off welfare, including marriage, relocation or death. Ignoring these factors distorts any estimation of employment effects, and the evaluation team therefore conducted a follow-up check on the residence records and social insurance numbers of all the 464 people in the program and the control group who left the rolls in 2000. Data was only found for 138 people; residual households were eliminated from the data set. As the follow-up could only be made for 2000, the following empirical analyses have to be limited to this time period even though the field experiment continued for another nine months.

\section{Treatment, Outcome, Identification}

The definition of treatment in this case is - like with the Canadian SSP - the information about the potential benefit of a time-restricted employee subsidy. TNIT was implemented correctly - as described above - and treatment can thus be assumed for the program group in Mannheim. Nevertheless, as status quo and TNIT might be difficult to understand in detail so we checked how well welfare recipients understood the TNIT net income line and break-even gross income. 450 program group members received a reminder by the public assistance authority and were invited to an oral interview at the office. However, only 46 $(12 \%)$ of those actually invited appeared for an interview between July and October 2000. Several questions were especially constructed to check people's understanding of the financial incentive scheme and included several examples of part-time and full-time jobs. Two results emerged: First, people appeared to have understood the TNIT principle. Most long-term unemployed people interviewed realised that they would retain - if not all of it as would be the case if they were moonlighting. Second, most of the long-term unemployed people were unclear about their break-even point. Single people in particular overestimated the break-even. More accurate guesses were made by most single mothers with one child (see IAW 2001).

Several outcomes are interesting as far as evaluation of TNIT is concerned: First, participation is a natural outcome of interest in this program. Second, although it would have been interesting to have found out more about hours of work, we did not receive any information about this topic. Instead, what we did obtain was net income data of the type which is rel- 
evant for administrators when calculating supplementary public assistance, and this is used for Tobit estimations. Third, it would be interesting as a follow-up to know more about how long people continued to be employed in particular jobs after the time limit expires. Fourth, it would be possible to analyse the working poor phenomena if systematic follow-up information was available. Some follow-up information for one point of time could be gathered for some sites and this is included in the final reports. However, budget constraints prevented any serious follow-up work being done.

Due to data constraints, the fundamental evaluation problem which needs to be solved is the participation decision, and this is standard in the literature (see e.g. Smith/Todd 2005). Let $D_{i}$ be a dummy variable that takes the value 1 if long-term unemployed are treated, i.e. live in the program district and receive the offer of TNIT and 0 otherwise. Let $Y_{i}$ be the outcome variable which is 1 if the individual is regularly employed at a given date. More precisely, $Y_{1 i}$ is the outcome in case of treatment and $Y_{0 i}$ is the outcome in case of non-treatment. We are actually interested in the treatment effect

$$
\Delta_{i}=Y_{1 i}-Y_{0 i}
$$

But it is never possible to observe $Y_{1 i}$ and $Y_{0 i}$ for the same individual at the same time, so that $\Delta_{i}$ cannot be measured directly. This is the fundamental evaluation problem.

Estimation of the treatment effect by matching relies on two non-testable identifying assumptions. The most common parameter of interest in most evaluation studies is the average effect of treatment on the treated (ATT),

$$
A T T=E\left(Y_{1}-Y_{0} \mid D=1\right)=E\left(Y_{1} \mid D=1\right)-E\left(Y_{0} \mid D=1\right) .
$$

which estimates the average impact of the program among those participating in it. In general it is not an option to simply take $Y_{1}$ from the treated $(D=1)$ and $Y_{0}$ from the non-treated $(D=0)$ due to possible selection bias. If caseworkers' selection criteria are correlated with outcome, we will have a selection bias:

$$
E\left(Y_{0} \mid D=1\right) \neq E\left(Y_{0} \mid D=0\right)
$$

Identification is due to the selection on observables assumption, i.e. assumptions for probit analyses and matching that identify ATT are the following:

$$
\begin{gathered}
Y_{0} \perp D \mid X \\
\operatorname{Pr}(D=1 \mid X)<1
\end{gathered}
$$


Assumption (4) is called the Conditional Independence Assumption (CIA). It states that once we control for a vector $X$ of observable characteristics, the outcome in case of not being treated, $Y_{0}$, does not depend on participation. This is a critical assumption, because all characteristics that influence both participation and outcome have to be observed. Assumption (5) is called the common support condition. If it does not hold, e.g. $\operatorname{Pr}(D=1 \mid X)=1$, then there is no individual with characteristics $X$ who is not treated. In other words: there is no common support for $X$. In this case it is not possible to estimate the counterfactual $E\left(Y_{0} \mid D=1, X\right)$, even if assumption (4) holds.

The crucial question is whether the identifying assumption that welfare recipients in the southern part of Mannheim (control district) behave in the same way as the unobserved counterfactuals in the northern part of Mannheim (program district). If we had sufficient information on covariates that influence both participation and outcome, i.e., the Conditional Independence Assumption (CIA) held, and common support is fulfilled we could use matching and probit as an evaluation strategy. However, our data set is restricted.

Heckman et al. (1997) and Heckman et al. (1998) show that data quality is a crucial ingredient in any reliable estimation strategy. Control group data must satisfy the following criteria: (i) the same data sources must be used for the program and the control group, (ii) the program and the control group must reside in the same local labour market, and (iii) the data must contain a rich set of variables that affect both program participation and labor market outcomes.

Out data set fulfills the first two criteria, given that we have the same data source for both groups and we observe a control group from the same local labor market which is comparable in most observable characteristics according to t-Tests. The crucial issue is the third criterion. On the one hand we observe the most important determinants of the participation decision such as age, sex, household type, education and skill level and duration of unemployment (which is up to five years). On the other hand we do not observe individual employment history, and selection on unobservables could therefore play an important role. Furthermore, we do not observe pre-program data, but we could assume the household specific need standard as a proxy for pre-program outcome of long-term unemployed. Quality checks for matching such as pre-program tests and balancing score tests are not therefore feasible. This is why we decided to restrict our analysis on Probit and Tobit estimations and argue that results have to be interpreted with care. It is left to the reader to decide, whether there is sufficient information to justify the non-testable CIA which is a prerequisite in a strict sense 
for the causal interpretation of the following Probit-results.

If the selection-on-observables assumption is accepted by the reader, coefficients of the program group dummy in an average marginal effect Probit estimation could be interpreted as average treatment effects (ATE) of TNIT. The ATE is the outcome which would be produced if individuals were assigned treatment at random. It is defined as a weighted sum of the ATT and the average treatment effect on the untreated (ATU) in the literature (e.g. Blundell/Costa Dias 2002 and Blundell et al. 2003). Average marginal effects are accumulated and averaged individual marginal effects, not marginal effects evaluated at the mean. In our setting, the average marginal effect of the TNIT program dummy is identical with the ATE of TNIT.

\section{Econometric Strategy}

\subsection{Probit estimations}

As the first step in the empirical analyses, the welfare recipient's decision to take up employment $y_{i}^{*}$ is evaluated using simple maximum likelihood probit estimation. We assume that the utility of a welfare recipient taking up employment can be described by a linear combination of observable determinants and an i.i.d distributed random variable $\epsilon_{i}$ accounting for unobserved heterogeneity. As $y_{i}^{*}$ is unobservable we can only observe whether an individual chooses to start working or not. It is assumed that the individual chooses to work, i.e. the dependent variable $y_{i}^{*}$ has the value 1 , if the latent variable exceeds a certain threshold value $\mathrm{s}$, and 0 else. The threshold $\mathrm{s}$ is identical for all individuals and fixed as zero without loss of generality.

$$
y_{i}=\left\{\begin{array}{ll}
0 & \text { if } y_{i}^{*}=x_{i}^{\prime} \beta+\epsilon_{i} \leq 0 \\
1 & \text { if } y_{i}^{*}=x_{i}^{\prime} \beta+\epsilon_{i} \geq 0
\end{array} \quad \text { with } \epsilon_{i} \sim N\left(0, \sigma^{2}\right)\right.
$$

The probability $P\left(y_{i}=1\right)$ can be expressed as a value of a distribution function $F_{\epsilon_{i}}$. Using the distribution function of a standard normal distribution for $F_{\epsilon_{i}}$, a probit model is obtained. This is estimated by maximum likelihood estimation. To account for heteroscedasticity robust standard errors using the Huber/White sandwich estimator of variance are estimated.

The possible impact of TNIT on the decision to work is approximated by a dummy variable which is one for all individuals living in the program regions, and zero else. Other 
determinants of the probability of taking up working an individuals' sex, nationality and age. In order to account for possible human capital effects the duration of unemployment at the beginning of the experiment is also taken into account as an explanatory variable. The degree of individual education might be measured either by the level of school education or the level of vocational training.

As both variables for education are highly collinear, we include only dummy variables for the level of vocational training. As the type of household can be expected to have an impact on the decision to work, dummy variables for single people, lone parents (reference group) and couples with or without children are used. Table 1 provides the corresponding summary statistics focusing on all individuals that can be used for model estimation as details for all variables included are available. Table 1 reveals that the program group consists of very low qualified long-term unemployed who are unemployed up to five years. 
Table 1: Descriptive Statistics

\begin{tabular}{lccccc}
\hline Variable & $\mathrm{N}$ & mean & sd & min & $\max$ \\
\hline Take up of employment ( 1=yes) & 914 & .159 & .366 & 0 & 1 \\
Sex $(1=$ male) & 914 & .565 & .496 & 0 & 1 \\
Nationality ( $1=$ foreign) & 914 & .290 & .454 & 0 & 1 \\
Age in years & 914 & 39.612 & 11.635 & 19 & 64 \\
Duration of unemployment in months & 914 & 31.244 & 12.951 & 14 & 60 \\
Vocational training & & & & & \\
$\quad$ Unqualified (ref. group) & 914 & .584 & .493 & 0 & 1 \\
$\quad$ Apprenticeship or similar & 914 & .376 & .485 & 0 & 1 \\
$\quad$ University of applied sciences or university & 914 & .039 & .195 & 0 & 1 \\
School education & & & & & \\
$\quad$ No education & 903 & .163 & .369 & 0 & 1 \\
$\quad$ Low, medium secondary and comprehensive school & 903 & .616 & .487 & 0 & 1 \\
$\quad$ Grammar school & 903 & .221 & .415 & 0 & 1 \\
Type of household & & & & & \\
$\quad$ Single person & & & & \\
$\quad$ Lone parent (ref. group) & 914 & .556 & .497 & 0 & 1 \\
$\quad$ Couple without children & 914 & .152 & .359 & 0 & 1 \\
$\quad$ Couple with children & 914 & .118 & .323 & 0 & 1 \\
Group & 914 & .174 & .379 & 0 & 1 \\
$\quad$ Program group (1 = yes) & & & & & \\
$\quad$ Program group (incl. special districts) (1=yes) & 914 & .569 & .495 & 0 & 1 \\
\hline
\end{tabular}

Average marginal effects of probit estimations are presented in Table 2. Models (1) and (2) only differ in terms of the definition of the program group depending on whether the special districts, where TNIT was also offered, are included or not. Recall that the program was implemented in the northern part of Mannheim (program district) and in the centre (special districts) but that the control district (southern part of Mannheim) is only comparable with the program district excluding special districts.

To summarize the main result of the estimation: Despite controlling for a variety of individual characteristics such as sex, nationality, age, education, duration of unemployment and type of household, the TNIT dummy variable has a positive and significant impact on the participation probability for both models. The average marginal effect lies between 6.6 and 
6.8 percentage points depending on the model. It is left to the reader to decide whether the size of the effect is small, medium or large having table 1 in mind. ${ }^{12}$ The coefficients of the program group dummy could be interpreted as average treatment effects of TNIT if the reader accepts the selection-on-observables assumption.

While sex does not have a reliable impact on the decision to start working, nationality does: foreigners have a statistically significant higher probability of working than German welfare recipients with the same characteristics. The older the unemployed individuals are the lower is the probability that hey will take up work. Duration of unemployment also has a demonstrably significant impact on the probability of taking up work bearing in mind the importance of hysteresis effects. Lone parents c.p. have the highest probability of getting a new job, although the statistical significance of this finding is not known.

\footnotetext{
${ }^{12}$ We also checked Propensity Score Matching and found similar results. These results could be reported if referees found it useful even without quality checks such as pre-program test and balancing score test.
} 
Table 2: Probit Models for overall employment (average marginal effects)

\begin{tabular}{|c|c|c|}
\hline & $\begin{array}{c}\text { (1) } \\
\text { Model with } \\
\text { standard } \\
\text { program group }\end{array}$ & $\begin{array}{c}(2) \\
\text { Model with } \\
\text { program group } \\
\text { including } \\
\text { special districts }\end{array}$ \\
\hline Sex $(1=$ male $)$ & $\begin{array}{c}-0.0076 \\
(0.8)\end{array}$ & $\begin{array}{l}-0.0082 \\
(0.764)\end{array}$ \\
\hline Nationality $(1=$ foreign $)$ & $\begin{array}{c}0.064 \\
(0.065)^{*}\end{array}$ & $\begin{array}{c}0.0707 \\
(0.015)^{* *}\end{array}$ \\
\hline Age in years & $\begin{array}{r}-0.0017 \\
(0.171)\end{array}$ & $\begin{array}{l}-0.0021 \\
(0.069)^{*}\end{array}$ \\
\hline Duration of unemployment in months & $\begin{array}{c}-0.0028 \\
(0.009)^{* * *}\end{array}$ & $\begin{array}{c}-0.0033 \\
(0.001)^{* * *}\end{array}$ \\
\hline $\begin{array}{l}\text { Vocational training } \\
\text { Unqualified (ref. group) }\end{array}$ & & \\
\hline Apprenticeship or similar & $\begin{array}{l}0.0275 \\
(0.346)\end{array}$ & $\begin{array}{c}0.022 \\
(0.408)\end{array}$ \\
\hline University of applied sciences or university & $\begin{array}{l}0.0151 \\
(0.838)\end{array}$ & $\begin{array}{l}0.1131 \\
(0.111)\end{array}$ \\
\hline $\begin{array}{l}\text { Type of household } \\
\text { Lone parent (ref. group) }\end{array}$ & & \\
\hline Single person & $\begin{array}{l}-0.0642 \\
(0.129)\end{array}$ & $\begin{array}{r}-0.0615 \\
(0.116)\end{array}$ \\
\hline Couple without children & $\begin{array}{r}-0.0442 \\
(0.318)\end{array}$ & $\begin{array}{l}-0.0537 \\
(0.116)\end{array}$ \\
\hline Couple with children & $\begin{array}{l}-0.0235 \\
(0.589)\end{array}$ & $\begin{array}{l}-0.0206 \\
(0.182)\end{array}$ \\
\hline $\begin{array}{l}\text { Group } \\
\quad \text { Control group (ref. group - no offer of TNIT) }\end{array}$ & & \\
\hline Program group & $\begin{array}{c}0.066 \\
(0.016)^{* *}\end{array}$ & \\
\hline Program group (incl. Special districts) & & $\begin{array}{c}0.068 \\
(0.003)^{* * *}\end{array}$ \\
\hline Observations & 700 & 914 \\
\hline Log-likelihood & -276.94 & -375.59 \\
\hline Wald-test & $\begin{array}{c}30.03 \\
(0.001)^{* * *}\end{array}$ & $\begin{array}{c}49.09 \\
(0.000)^{* * *}\end{array}$ \\
\hline Pseudo- $R^{2}$ & 0.047 & 0.061 \\
\hline
\end{tabular}

Notes: Administrative data, Mannheim, 2000, p-values in parentheses. $* * * / * * / *$ indicate statistical significance at the 1, 5 and 10 percent level, respectively.

The next section presents some generalizations of simple probit estimation using additional information about the monthly net income of the employees applying Tobit estimation. Finally, we discuss ideas for further modeling options not all of which - owing to data restrictions - we were able to apply. 


\subsection{Tobit estimations and extensions}

The empirical analysis of the employment effects of TNIT has so far used simple maximum likelihood probit estimation to focus on the decision of welfare recipients to start a new job. Information about the monthly net income of job-starters has so far been neglected. But, as "it is inefficient to throw away information on the value of the dependent variable when it is available" (Tobin 1958, p. 25), in the following section Tobit models are additionally estimated allowing for continuous outcomes of the dependent variable for all individuals who take up a new job.

Again, the latent utility of a welfare recipient starting a new job with a specific monthly net income is modeled as a function of $x_{i}^{\prime} \beta$ and an i.i.d distributed random variable $\epsilon_{i}$ accounting for unobserved heterogeneity.

In this case, the Tobit model is given by

$$
y_{i}=\left\{\begin{array}{ll}
\text { income }_{i} & \text { if } y_{i}^{*}>0 \\
0 & \text { if } y_{i}^{*} \leq 0
\end{array} \quad \text { with } y_{i}^{*}=x_{i}^{\prime} \beta+\epsilon_{i}, \quad \epsilon_{i} \sim N\left(0, \sigma^{2}\right)\right.
$$

It differs from the probit model defined in Eq. (1.1) in that it maps from the latent variable to the observed variable and in that - in case of $y_{i}^{*}>0$ - the dependent variable becomes continuous. This type of model is often called a "censored regression model" as negative values of $y_{i}^{*}$ are mapped to zero. Estimation of the Tobit model is done by maximum likelihood estimation and is preferable to simple OLS regression for the restricted sample of the job-starters as the latter might lead to inconsistent estimates due to $E\left[y_{i} \mid y_{i}>0\right]>E\left[y_{i}\right]$. However, the estimation of a Tobit model might be very sensitive to a violation of the basic model assumptions, in particular to a violation of the assumptions of homoscedasticity and normality. We will come back to this point later. A further crucial assumption of the standard Tobit model to be checked is, that the process driving the decision to work or not can be explained by the same determinants as the process driving the decision "how much to work" as both processes are estimated in a single model. If this assumption was violated, more general sample selection models allowing for a separate estimation of both processes should be applied instead (see Heckman 1976, 1979).

Either a person's mean net income or the natural logarithm of the net income is used to check the sensitivity of the results for the continuous part of the dependent variable either. The results in Table 3 however - as well as further results - show that the conclusions do not depend on the shape of the dependent variable. 
Table 3: Determinants of the decision to work and how much to work - Results from ML Tobit estimations ${ }^{13}$

\begin{tabular}{|c|c|c|c|c|}
\hline & $(1)$ & $(2)$ & $(3)$ & $(4)$ \\
\hline & \multicolumn{2}{|c|}{$\begin{array}{c}\text { Models with } \\
\text { standard } \\
\text { program group }\end{array}$} & \multicolumn{2}{|c|}{$\begin{array}{c}\text { Models with } \\
\text { program group } \\
\text { including special } \\
\text { districts }\end{array}$} \\
\hline & $\begin{array}{l}\text { Monthly net } \\
\text { income: }\end{array}$ & $\begin{array}{l}\text { Log. monthly } \\
\text { net income }\end{array}$ & $\begin{array}{l}\text { Monthly net } \\
\text { income: }\end{array}$ & $\begin{array}{l}\text { Log. monthly } \\
\text { net income }\end{array}$ \\
\hline Sex $(1=$ male $)$ & $\begin{array}{c}-111.939 \\
(0.635)\end{array}$ & $\begin{array}{l}-0.919 \\
(0.559)\end{array}$ & $\begin{array}{l}-0.506 \\
(0.691)\end{array}$ & $\begin{array}{l}-0.506 \\
(0.691)\end{array}$ \\
\hline Nationality ( 1 = foreign) & $\begin{array}{l}438.144 \\
(0.061)^{*}\end{array}$ & $\begin{array}{c}2.939 \\
(0.061)^{*}\end{array}$ & $\begin{array}{c}3.142 \\
(0.012)^{* *}\end{array}$ & $\begin{array}{c}3.142 \\
(0.012)^{* *}\end{array}$ \\
\hline Age in years & $\begin{array}{l}-7.738 \\
(0.443)\end{array}$ & $\begin{array}{l}-0.037 \\
(0.581)\end{array}$ & $\begin{array}{l}-0.047 \\
(0.389)\end{array}$ & $\begin{array}{l}-0.047 \\
(0.389)\end{array}$ \\
\hline $\begin{array}{l}\text { Duration of unemployment } \\
\text { in months }\end{array}$ & $\begin{array}{l}-18.855 \\
(0.026)^{* *}\end{array}$ & $\begin{array}{c}-0.116 \\
(0.039)^{* *}\end{array}$ & $\begin{array}{c}-0.124 \\
(0.007)^{* * *}\end{array}$ & $\begin{array}{c}-0.124 \\
(0.007)^{* * *}\end{array}$ \\
\hline \multicolumn{5}{|l|}{$\begin{array}{l}\text { Vocational training } \\
\text { Unqualified (ref. group) }\end{array}$} \\
\hline Apprenticeship or similar & $\begin{array}{l}118.568 \\
(0.600)\end{array}$ & $\begin{array}{c}0.598 \\
(0.692)\end{array}$ & $\begin{array}{l}-0.009 \\
(0.994)\end{array}$ & $\begin{array}{l}-0.009 \\
(0.994)\end{array}$ \\
\hline $\begin{array}{l}\text { University of applied } \\
\text { sciences or university }\end{array}$ & $\begin{array}{l}206.028 \\
(0.695)\end{array}$ & $\begin{array}{c}1.699 \\
(0.628)\end{array}$ & $\begin{array}{c}4.015 \\
(0.100)\end{array}$ & $\begin{array}{c}4.015 \\
(0.100)\end{array}$ \\
\hline \multicolumn{5}{|l|}{$\begin{array}{l}\text { Type of household } \\
\text { Lone parent (ref. group) }\end{array}$} \\
\hline Single person & $\begin{array}{c}-470.017 \\
(0.119)\end{array}$ & $\begin{array}{l}-3.168 \\
(0.117)\end{array}$ & $\begin{array}{c}-2.930 \\
(0.081)^{*}\end{array}$ & $\begin{array}{c}-2.930 \\
(0.081)^{*}\end{array}$ \\
\hline Couple without children & $\begin{array}{c}-646.050 \\
(0.123)\end{array}$ & $\begin{array}{l}-4.095 \\
(0.140)\end{array}$ & $\begin{array}{l}-3.825 \\
(0.094)^{*}\end{array}$ & $\begin{array}{c}-3.825 \\
(0.094)^{*}\end{array}$ \\
\hline Couple with children & $\begin{array}{c}-189.539 \\
(0.594)\end{array}$ & $\begin{array}{l}-1.951 \\
(0.416)\end{array}$ & $\begin{array}{l}-1.852 \\
(0.352)\end{array}$ & $\begin{array}{l}-1.852 \\
(0.352)\end{array}$ \\
\hline $\begin{array}{l}\text { Group } \\
\text { Control group(ref. group - } \\
\text { no offer of TNIT) }\end{array}$ & & & & \\
\hline Program group & $\begin{array}{c}519.596 \\
(0.000)^{* * *}\end{array}$ & $\begin{array}{c}3.363 \\
(0.000)^{* * *}\end{array}$ & ( & \\
\hline $\begin{array}{l}\text { Program group (incl. } \\
\text { special districts) }\end{array}$ & & & $\begin{array}{c}3.287 \\
(0.005)^{* * *}\end{array}$ & $\begin{array}{c}3.287 \\
(0.005)^{* * *}\end{array}$ \\
\hline Constant & $\begin{array}{l}-1,034.576 \\
(0.035)^{* *}\end{array}$ & $\begin{array}{c}-7.349 \\
(0.025)^{* *}\end{array}$ & $\begin{array}{c}-6.276 \\
(0.019)^{* *}\end{array}$ & $\begin{array}{c}-6.276 \\
(0.019)^{* *}\end{array}$ \\
\hline Observations & 679 & 679 & 886 & 886 \\
\hline
\end{tabular}

Notes: p-values in parentheses. ${ }^{* * *} / * * / *$ indicate statistical significance at the 1,5 and 10 percent level, respectively.

\footnotetext{
${ }^{13}$ The number of individuals is slightly smaller than in probit estimation due to missing values of the monthly net income.
} 
The Tobit model assumes that the decision to work and the decision "how much" to work are estimated at the same time. The parameters in $B$ can be interpreted in two ways: on the one hand, they represent the impact of a change in an independent variable on the probability of taking up employment. On the other hand, they represent the impact of an independent variable on the level of income. To check for the validity of this crucial assumption, the marginal effects of the explaining variables on the probability of being uncensored and on the latent variable should have the same sign for all explaining variables.

A closer look at Table 4 shows that this assumption is met for model (1) and that Tobit is the correct specification in this case.

In general, it can be concluded that the results of simple probit estimations are still confirmed even when the more general Tobit model is applied. Living in the program group region where TNIT was offered also has a c.p. statistically significant impact on the latent variable driving the individual's decision process. However, as the probability of getting a new job is rather small, the marginal impact on $y_{i}$ is also rather moderate (roughly $60 \mathrm{DM}$ ) - see Table 3 , which provides information about the marginal effect of a change in a regressor upon the expected outcome $y_{i}$ given by the product of the coefficient and the probability of having a positive income. If the probability is one, the marginal effect equals the regression coefficient in a linear model. 
Table 4: Marginal effects for model (1) - Results from ML Tobit estimations

\begin{tabular}{|c|c|c|c|}
\hline & $\begin{array}{c}\text { Probability of } \\
\text { being } \\
\text { uncensored }\end{array}$ & $\begin{array}{c}\text { Marginal effect } \\
\text { on the latent } \\
\text { variable } \\
\end{array}$ & $\begin{array}{c}\text { Marginal effect: } \\
\text { Unconditional } \\
\text { Expected Value }\end{array}$ \\
\hline Sex $(1=$ male $)$ & $\begin{array}{l}-0.013 \\
(0.632)\end{array}$ & $\begin{array}{c}-111.939 \\
(0.635)\end{array}$ & $\begin{array}{l}-12.419 \\
(0.632)\end{array}$ \\
\hline Nationality ( 1 = foreign) & $\begin{array}{c}.0555 \\
(0.042)^{* *}\end{array}$ & $\begin{array}{l}438.144 \\
(0.061)^{*}\end{array}$ & $\begin{array}{c}54.288 \\
(0.042)^{* *}\end{array}$ \\
\hline Age in years & $\begin{array}{l}-0.001 \\
(0.443)\end{array}$ & $\begin{array}{l}-7.738 \\
(0.443)\end{array}$ & $\begin{array}{l}-0.851 \\
(0.443)\end{array}$ \\
\hline \multicolumn{4}{|l|}{ Duration of unemployment } \\
\hline in months & $\begin{array}{c}-0.002 \\
(0.026)^{* *}\end{array}$ & $\begin{array}{c}-18.855 \\
(0.026)^{* *}\end{array}$ & $\begin{array}{c}-2.074 \\
(0.026)^{* *}\end{array}$ \\
\hline \multicolumn{4}{|l|}{$\begin{array}{l}\text { Vocational training } \\
\text { Unqualified (ref. group) }\end{array}$} \\
\hline Apprenticeship or similar & $\begin{array}{c}.0140 \\
(0.595)\end{array}$ & $\begin{array}{c}118.568 \\
(0.600)\end{array}$ & $\begin{array}{l}13.261 \\
(0.595)\end{array}$ \\
\hline $\begin{array}{l}\text { University of applied scien } \\
\text { or university }\end{array}$ & $\begin{array}{c}.0259 \\
(0.674)\end{array}$ & $\begin{array}{c}206.028 \\
(0.695)\end{array}$ & $\begin{array}{l}25.098 \\
(0.674)\end{array}$ \\
\hline \multicolumn{4}{|l|}{ Type of household } \\
\hline Single person & $\begin{array}{l}-0.056 \\
(0.111)\end{array}$ & $\begin{array}{c}-470.017 \\
(0.119)\end{array}$ & $\begin{array}{l}-53.537 \\
(0.111)\end{array}$ \\
\hline Couple without children & $\begin{array}{l}-0.062 \\
(0.203)\end{array}$ & $\begin{array}{c}-646.050 \\
(0.123)\end{array}$ & $\begin{array}{l}-55.182 \\
(0.203)\end{array}$ \\
\hline Couple with children & $\begin{array}{l}-0.021 \\
(0.612)\end{array}$ & $\begin{array}{c}-189.539 \\
(0.594)\end{array}$ & $\begin{array}{r}-19.480 \\
(0.612)\end{array}$ \\
\hline $\begin{array}{l}\text { Group } \\
\text { Control group (ref. group } \\
\text { no offer of TNIT) }\end{array}$ & & & \\
\hline Program group & $\begin{array}{c}.062 \\
(0.010)^{* * *}\end{array}$ & $\begin{array}{c}519.596 \\
(0.000)^{* * *}\end{array}$ & $\begin{array}{c}59.735 \\
(0.010)^{* * *}\end{array}$ \\
\hline Constant & $\begin{array}{l}-0.1209318 \\
(0.034) * *\end{array}$ & $\begin{array}{l}-1,034.576 \\
(0.035)^{* *}\end{array}$ & $\begin{array}{l}-113.820 \\
(0.034)^{* *}\end{array}$ \\
\hline Observations & & 679 & \\
\hline
\end{tabular}

Notes: p-values in parentheses. ${ }^{* * *} / * * / *$ indicate statistical

significance at the 1,5 and 10 percent level, respectively.

Furthermore, the Tobit estimator might be inconsistent due to a violation of further model 
assumptions. It would be particularly important to examine wether assumptions of homoscedasticity and of normality can be verified.

It is well known that the problem of heteroscedasticity is much more serious in Tobit estimation than in probit. The degree of censoring which is very high in our dataset might be a primary determinant for heteroscedasticity (see Greene 2003). A Lagrange multiplier test on the existence of homoscedasticity, however, does not lead to a rejection of the null hypothesis of homoscedasticity. ${ }^{14}$

However, the assumption of normality seems to be violated instead. A conditional moments test for skewness and kurtosis based upon the framework of Pagan and Vella (1989) - see Wooldridge 2002, p. 206f. - rejects the null hypothesis of normality of the errors at a $1 \%$ level of significance. Though a comparison of the density of the estimated residuals with the density of the corresponding normal distribution might give the impression that differences are not that large and in particular, though the results of the upper Tobit estimations seem to be plausible, this misspecification might have profound consequences for the validity of the estimation (and also for the validity of the test on homoscedasticity).

A preferable alternative would be to use an estimator which is robust to changes in the distribution and to the existence of heteroscedasticity. Powell (1984) suggests an estimator that is based on the more robust least absolute deviations (LAD) estimator, the so called censored least absolute deviations estimator (CLAD). This is based on an iterative procedure starting from running LAD on the entire sample, then dropping observations for which the predicted value is negative and rerunning LAD on this new sample. This procedure is repeated until the estimates stop changing (see Johnston/DiNardo 1997: 444f.). However, two problems hamper the application of CLAD to our sample. First, as the number of censored observations is too high and the median is zero LAD estimation does not work. Second, one should be cautious when implementing CLAD with small amounts of data though Monte Carlo simulations suggest that it might perform well.

A second method suggested by Powell is symmetrically trimmed least squares (STLS). The basic idea of this method is that standard OLS would produce consistent estimates of the parameters if the error term was symmetrically distributed around zero. As censoring intro-

\footnotetext{
${ }^{14}$ The test on heteroscedasticity was based upon the alternative that $\sigma_{\epsilon_{i}}^{2}=\sigma^{2} * \exp \left(z_{i}^{\prime} \alpha\right)$ wherby $z_{i}^{\prime}$ is a vector of explaining variables not including an intercept term. THe null hypotheses corresponds to $\alpha=0$ which implies that the variance of $\epsilon_{i}$ is $\sigma^{2}$. See Wooldridge 2002: 205f. or Greene 2003 for more details.
} 
duces asymmetry into the distribution, symmetry is regained by also truncating observations on the other side of the distribution. However, this method is most useful when the amount of censoring is not excessively severe and the amount of data is not too limited. We tried to estimate the corresponding STLS model, but the incremental loss of data was too large and it was not therefore possible to achieve satisfying convergence. Unfortunately, these data restrictions mean we have not so far been able to realize a more robust estimation to check the robustness of our conclusions against the problem of non-normality.

As described before, the Tobit model assumes that the decision whether or not to work and how much to work may be explained by the same underlying latent process. This assumption proved to be valid in our case.

We might therefore expect that the estimation of a more general sample selection model allowing for a separate estimation of both processes would not help to improve the results. Anyhow, as our upper results suffer from violation of the normality assumption and to further examine the stability of our conclusions, we additionally estimated sample selection models by using Heckman two-step estimation method. To summarize, in any case regardless of whether we included a few variables in the selection equation or the complete set of variables - the income equation appeared to forfeit any relevance it may have had at all if allowance was made for a separate estimation of both processes. With respect to our analyses this means that we have to be very careful in interpreting the Tobit results as a profound explanation for the decision of how much to work. Whatever method of estimation is used, we are, however,

able to prove a (small) positive impact of the supply of TNIT (including the nationality of the unemployed person and duration of unemployment) on the welfare recipient's decision to work. Our experiment therefore definitely helped to provide valuable insights into the effects of TNIT in the participation decision. There are, however, still many shortcomings which will need to be tackled in the course of further research.

\section{Conclusions}

For the first time in Germany field experiments with control groups were conducted between 1999 and 2002 to evaluate an active labour market program prior to its nationwide implementation. To date this has usually been done by implementing a program and subsequently evaluating it using non experimental methods (see Fitzenberger/Hujer 2002 and Schmidt et 
al. 2001 for surveys). In most cases evaluation studies have only been based on descriptive statistics without any control group concept.

To summarize the most important results: (1) TNIT is not associated with positive or negative employment effects if the relevant program is not implemented properly by local administrators i.e. if treatment is not assured. Because treatment is the provision of information about a potential benefit if a low-paid job is accepted, TNIT is very sensitive to implementation issues; (2) Treatment was assured in the city of Mannheim where a quasi experiment with a control group in the same local labour market (site randomization) was conducted. We find positive employment effects with respect to the participation decision. TNIT recipients have a higher probability of participating in the labour market than a control group in the same local labour market. The average treatment effect is about 6.8 percentage points if the reader accepts the selection on observables assumption.

The results presented here are in line with international experiences with similar financial incentives in Canada and Switzerland. Card (2000) and Michalopoulos et al. (2005) summarize the findings from the "Self Sufficiency Project": a large scale social experiment in Canada that was conducted to evaluate financial incentives for single mothers on the rolls. The most important results: Enhanced incentives induce a significant fraction of welfare recipients to leave the program and enter work. They also have a relatively large antipoverty effect. Furthermore, they can actually be associated with fiscal savings if incentives are offered to relatively short-term recipients. Gerfin/Lechner (2002) evaluate the effects of active labour market policy in Switzerland in the second half of the 1990s. They find that a financial incentive scheme called Temporary Wage Subsidy appears to be the one clearly successful program in terms of increasing opportunities in the labour market.

Social experimental culture in Germany lags far behind standards in the U.S. or the U.K.. Scientific field research is confronted by problems which would probably astonish researchers working in the same field in the Anglo-Saxon countries. Nevertheless, these obstacles to research are very real for economists in Germany. The results presented in this paper should be seen against this background. Obviously, many interesting questions for researchers remain open due to pitfalls in the implementation process the restricted involvement of local administrators and budget constraints for academic research financed by the states' Ministries of Social Affairs.

However, evaluation culture in Germany has dramatically changed in the wake of the four 
"Hartz laws". The Federal Ministry of Labor mandated two well-known German Economic Research Institutes - the Essen-based RWI and the Mannheim-based ZEW - to develop non-experimental evaluation designs with control groups in 2003 (see Fertig/Kluve 2004 and Hagen/Spermann 2004). Most data will be accessible via scientific use files.

TNIT was legally implemented in January 2004 by the Hartz IV Act (see Viertes Gesetz 2003) on the basis of the small positive employment effects on the micro-level found in the evaluation and documented in the final reports in 2002 as well as on the basis of positive international experiences with "carrot incentives to complement the stick" of sanctions for welfare recipients. However, the political reality is that nationwide TNIT assigns a crucial role to case managers. It is they who decide whether TNIT will be offered to welfare recipients or not.

A nationwide TNIT is a new opportunity to evaluate this program more broadly by nonexperimental methods. Hagen/Spermann (2004) set out an agenda on how to evaluate TNIT between 2004 and 2008. They suggest that microeconometric evaluation should distinguish between three economic variables to measure the program's success, and macroevaluation should use regional variations between labour market districts to evaluate the program. For microeconometric evaluation purposes three economic effects are of interest. First, the transition from unemployment to employment with TNIT. Second, the transition from subsidized employment to unsubsidized employment. Third, the duration of unsubsidized employment after a subsidized employment spell. Treatment and outcome variables depend on the issue addressed. First, the relevant treatment for evaluating the transition from unemployment to subsidized employment is the offer of a potential benefit by case managers whereby the outcome variable is participation in the labour market. In this case, the case manager's decision enables a control group to be constructed. Second, in order to evaluate the second transition from subsidized employment to unsubsidized unemployment treatment must be defined as employment with TNIT and outcome as transition in non-subsidized employment with TNIT recipients as the program group and employed people without a TNIT-spell as the control group. Third, in order to evaluate the duration of employment, treatment must be defined as TNIT payment and the outcome as duration of employment following transition into regular employment. The program group would be made up of people with TNIT and the control group of people without TNIT. Differentiated program and control group comparisons may yield positive employment effects with respect to all three economic variables. A macroevaluation may reveal that indirect effects such as deadweight and displacement do 
not play a role.

Time-restricted financial incentive schemes such as TNIT and SSP are just one way of circumventing the poverty trap for a certain time period. At best, TNIT might provide a stepping stone into the normal labour market and might prove fiscally attractive for policymakers. However, evaluation strongly suggests that this instrument does not offer a panacea for the labour market. At best, TNIT might be one possible piece in a larger puzzle - a broader and more coherent employment strategy that activates the unemployed rather than passively paying unemployment benefits or public assistance.

Reforming active labour market policy in Germany has become an important issue, partidulary in academic debate (e.g. Schmidt et al. 2001 and Fitzenberger/Hujer 2002). Several authors favour financial incentive schemes rather than public employment programs (e.g. Fertig et al. 2002). Reforming public assistance has also become an important issue, although radical reform proposals have attracted very little support in the political debate (e.g. Sinn et al. 2002). More moderate reform proposals have been made by the Council of Economic Advisers, although they have not yet been subject to intensive political debate (Sachverständigenrat 2003). Finally, welfare-to-work strategies have grown increasingly popular since 2004 (Zimmermann 2003). However, this strategy could prove very expensive in fiscal terms if it is mainly public sector jobs which have to be provided for welfare recipients. 


\section{References}

Adema, Willem and Donald Gray and Sigrun Kahl (2003): Social Assistance in Germany, OECD Labour Market and Social Policy Occasional Papers No. 58.

Bertrand, Marianne and Sendhil Mullainathan (2004): Are Emily and Greg more employable than Lakisha and Jamal? A Field Experiment on Labor Market Discrimination, American Economic Review, 94(4), 991-1013.

Blank, Rebecca, David E. Card and Philip K. Robins (2000): Financial Incentives for Increasing Work and Income Among Low-Income Families, in: Card, David E. and Rebecca M. Blank, Finding Jobs, Work and Welfare Reform, Russell Sage Foundation, New York, 373-419.

Blundell, Richard (2002): Welfare-to-Work: Which Policies Work and Why?, Keynes Lecture in Economics 2001, Proceedings of the British Academy, 117, 477-524.

Blundell, Richard and Hilary Hoynes (2004): In-Work Benefit Reform and the Labour Market, in: Blundell, Richard and David Card and Richard B. Freeman (eds.), Seeking a Premier League Economy, University of Chicago Press, Chicago, 411-459.

Blundell, Richard and Monica Costa Dias (2002): Alternative approaches to evaluation in empirical microeconomics, Portuguese Economic Journal, 1, 91-115.

Card, David E. (2000): Reforming the Financial Incentives of the Welfare System, IZA Discussion Paper No. 172, Bonn.

Crawford, Claire and Jonathan Shaw (2004): A Survey of the UK Benefit System, Institute for Fiscal Studies, Briefing Note No. 13.

Dann, Sabine, Andrea Kirchmann, Alexander Spermann and Jürgen Volkert (2001): Einstiegsgeld in Baden-Württemberg, Eine Zwischenbilanz des baden-württembergischen Modellversuchs zum Kombi-Einkommen, ed. by Sozialministerium Baden-Württemberg, Stuttgart.

Dann, Sabine, Andrea Kirchmann, Alexander Spermann and Jürgen Volkert (2002a), "Modellversuch Hessischer Kombilohn. Wissenschaftliche Begleitforschung des hessischen Modellversuchs", Schlussbericht des Instituts für angewandte Wirtschaftsforschung (IAW), Tübingen. 
Dann, Sabine, Andrea Kirchmann, Alexander Spermann and Jürgen Volkert (2002b), "Einstiegsgeld in Baden-Württemberg", Schlussbericht des Instituts für angewandte Wirtschaftsforschung (IAW), ed. by Sozialministerium Baden-Württemberg, Stuttgart.

Dickert, Stacy and Scott Houser and John Karl Scholz (1995): The Earned Income Tax Credit and Transfer Programs: A Study of Labor Market and Program Participation, in: Poterba, James M. (ed.), Tax Policy and the Economy, 9, 1-43.

Duncan, Alan and Christopher Giles (1996): Labour Supply Incentives and Recent Family Credit Reforms, The Economic Journal, 106, 142-155.

Falk, Armin and Ernst Fehr (2003): Why labour market experiments?, Labour Economics, 10, 399-406.

Fertig, Michael, Schmidt, Christoph M. and Hilmar Schneider (2002): Active Labor Market Policy in Germany - Is there a successful Policy Strategy?, IZA DP No. 576.

Fertig, Michael and Jochen Kluve (2004): A Conceptual Framework for the Evaluation of Comprehensive Labor Market Policy Reforms in Germany, IZA DP No. 1099.

Fitzenberger, Bernd and Reinhard Hujer (2002): Stand und Perspektiven der Evaluation der Aktiven Arbeitsmarktpolitik in Deutschland, Perspektiven der Wirtschaftspolitik 3 (2), 139-158.

Gerfin, Michael and Michael Lechner (2002): A Microeconometric Evaluation of the Active Labour Market Policy in Switzerland, Economic Journal, 112, 854-893.

Greenberg, David and Mark Shroder (2004): The Digest of Social Experiments, 3rd ed., The Urban Institute Press, Washington D.C.

Greenberg, David and Mark Shroder and Matthew Onstott (1999): The Social Experiment Market, Journal of Economic Perspectives, 13 (3), 157-172.

Greene, W. H. (2003): Econometric Analysis, Fifth Edition, Prentice Hall.

Hagen, Tobias and Alexander Spermann (2004): Zusammenführung von Arbeitslosen- und Sozialhilfe, in: Hagen, Tobias and Alexander Spermann (ed.), Evaluation der HartzGesetze - Methodische Vorüberlegungen, ZEW Wirtschaftsanalysen, Vol. 74, 117-129. 
Heckman, James J. (1976): The common structure of statistical models of truncation, sample selection model, and limited dependent variables and a simple estimator for such models, The annals of Economic and Social Measurement, 5, 4, 475-492.

Heckman, James J. (1979): Sample selection bias as a specification error, Econometrica, 47, 1, 153-161.

Heckman, James J., Ichimura, Hide, Smith, Jeffrey A. and Petra Todd (1998): Characterizing selection bias using experimental data. Econometrica, 66, 1017-1098.

Heckman, James J., Ichimura, Hide and Petra Todd (1997): Matching as an econometric evaluation estimator: Evidence form evaluating a job training programme, Review of Economic Studies, 64, 605-654.

Heckman, James J. and Jeffrey A. Smith (1995): Assessing the Case for Social Experiments, Journal of Economic Perspectives, 9, 85-110.

Institut für Angewandte Wirtschaftsforschung IAW (2001): Modellversuch Einstiegsgeld in Baden-Württemberg, Mündliche Befragung in der Stadt Mannheim, unpublished.

Jerger, Jürgen and Alexander Spermann (1997): Promoting Low-Wage Employment: The Case for a Targeted Negative Income Tax, Jahrbuch für Wirtschaftswissenschaften (Review of Economics), 45, 269-287.

Jerger, Jürgen and Alexander Spermann (2003): Alternative Subsidies for Low-Wage Employment, in: Addison, John T. and Paul J.J. Welfens (ed.), Labor Markets and Social Security, 2nd ed., Springer, Berlin, 83-99.

Johnston, Jack and John DiNardo (1997): Econometric Methods, Fourth Edition. McGraw Hill Co., New York, NY.

Meyer, Bruce D. and Douglas Holtz-Eakin (2002): Making Work Pay, The Earned Income Tax Credit and Its Impact on America's Families, Russell Sage Foundation, New York.

Michalopoulos, Charles, Robins, Philip K. and David Card (2005): When financial work incentives pay for themselves: evidence from a randomized social experiment for welfare recipients, Journal of Public Economics, 89, 5-29.

Moffitt, Robert A. (ed.) (2003): Means-Tested Transfer Programs in the United States, The University of Chicago Press. 
OECD (1997): Making Work Pay, Paris.

OECD (2003): OECD Employment Outlook, Paris.

Pagan, A. and Vella, F. (1989): Diagnostic Tests for Models Based on Individual Data: A Survey, Journal of Applied Econometrics, 4, Supplement, 529- 559.

Powell, J. L. (1984): Least absolute deviations estimation for the censored regression model, Journal of Econometrics, 25, 303-325.

Powell, J. L. (1986): Symmetrically trimmed least squares estimation for Tobit models, Econometrica, 54, 6, 1435-1460.

Robins, Philip K. and Robert G. Spiegelman (2001): Reemployment Bonuses in the Unemployment Insurance System, W.E. Upjohn Institute, Michigan.

Rosholm, Michael and Lars Skipper (2003): Is Labour Market Training a Curse for the Unemployed? Evidence from a Social Experiment, IZA DP No. 716.

Sachverständigenrat zur Begutachtung der gesamtwirtschaftlichen Entwicklung (2003): Staatsfinanzen konsolidieren - Steuersystem reformieren, Jahresgutachten 2003/04, Wiesbaden.

Schmidt, Christoph M., Klaus F. Zimmermann, Michael Fertig and Jochen Kluve (2001): Perspektiven der Arbeitsmarktpolitik: Internationaler Vergleich und Empfehlungen für Deutschland, Berlin.

Smith, Jeffrey A. and Petra Todd (2005): Does Matching Overcome Lalonde's Critique of Nonexperimental Estimators?, Journal of Econometrics, 125, 305-353.

Sinn, Hans-Werner, Christian Holzner, Wolfgang Meister, Wolfgang Ochel and Martin Werding (2002): Aktivierende Sozialhilfe, Ein Weg zu mehr Beschäftigung und Wachstum, Sonderausgabe Institut für Wirtschaftsforschung (IFO), 55, 2002.

Spermann, Alexander (1996): Das "Einstiegsgeld" für Langzeitarbeitslose, Wirtschaftsdienst, $76,240-246$.

Spermann, Alexander (1999): Fighting Long-term Unemployment with Targeted Employment Subsidies: Benefit Transfer Programme (BTP) versus Targeted Negative Income Tax (TNIT), Jahrbücher für Nationalökonomie und Statistik (Journal of Economics and Statistics), Vol. 218/5+6, 647-657. 
Spermann, Alexander (2001): Negative Einkommensteuer, Lohnsubventionen und Langzeitarbeitslosigkeit, Finanzwissenschaftliche Schriften, Vol. 104, Frankfurt am Main.

Tobin, James (1958): Estimation of Relationships for Limited Dependent Variables, Econometrica, 26, 24-36.

Viertes Gesetz für moderne Dienstleistungen am Arbeitsmarkt v. 24.12.2003, Bundesgesetzblatt Jahrgang 2003, Teil I Nr. 66, 2954-3000.

Van den Berg, Gerard J. and Bas van der Klaauw (2001): Counseling and Monitoring of Unemployed Workers: Theory and Evidence from a Controlled Social Experiment, IZA DP No. 374, Bonn.

Winter-Ebmer, Rudolf (1998): Potential Unemployment Benefit Duration and Spell Length: Lessons from a Quasi-Experiment in Austria, Oxford Bulletin of Economics and Statistics, $60(1), 33-45$.

Wooldridge, J. M. (2002): Econometric Analysis of Cross Section and Panel Data, The MIT Press, Cambridge.

Zimmermann, Klaus F. (2003): Beschäftigung im Niedriglohnbereich, Vierteljahresheft zur Wirtschaftsforschung, 72, 1, S. 11-24, DIW Berlin. 


\begin{tabular}{|c|c|c|}
\hline 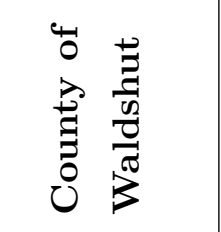 & 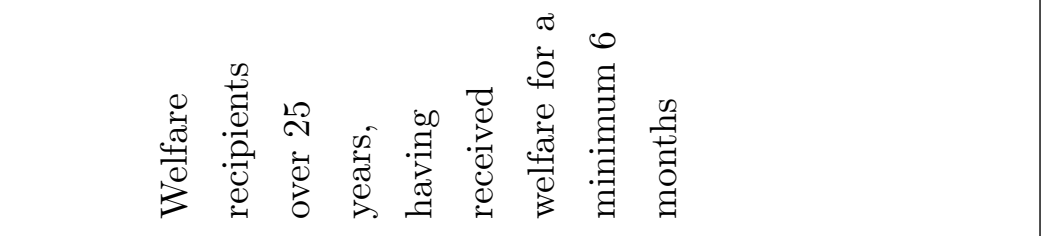 & 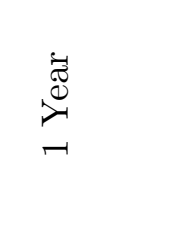 \\
\hline 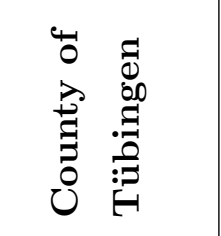 & 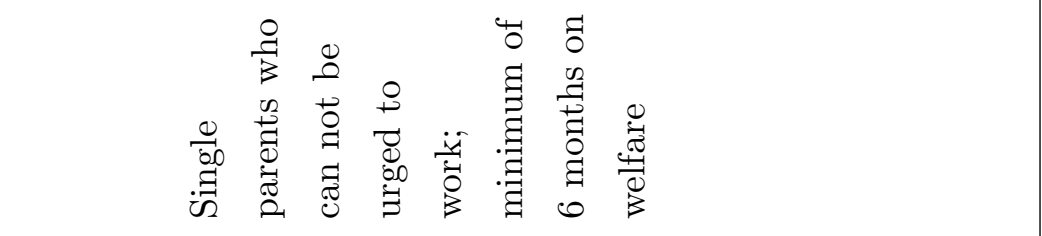 & 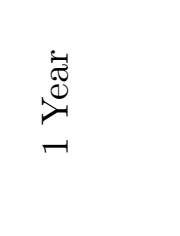 \\
\hline 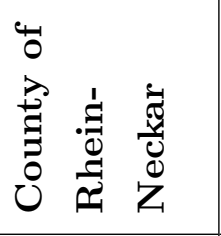 & 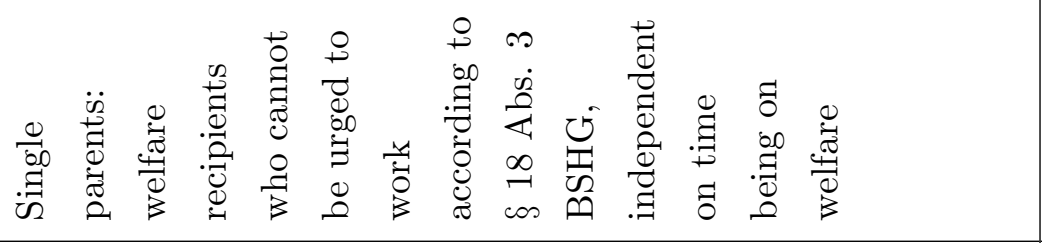 & 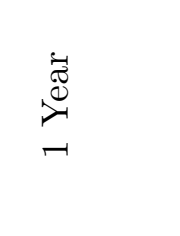 \\
\hline 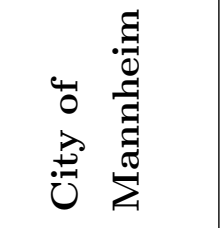 & 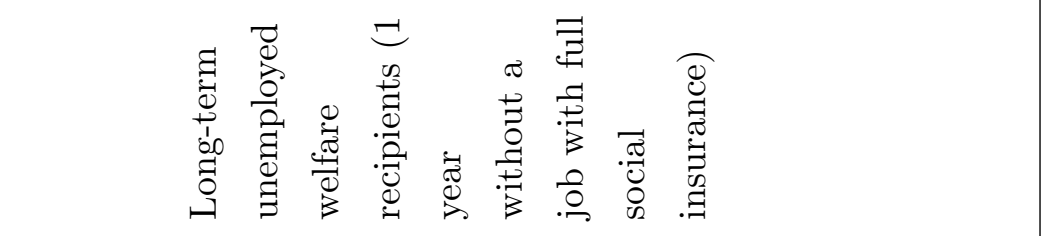 & 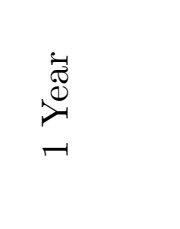 \\
\hline 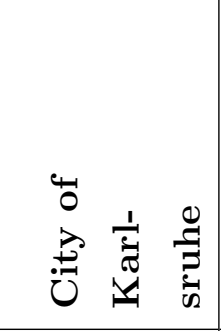 & 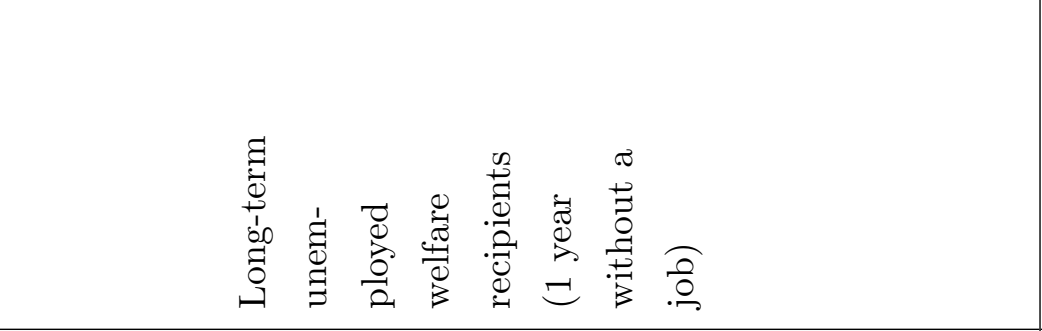 & 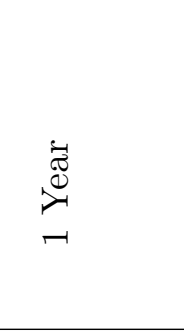 \\
\hline 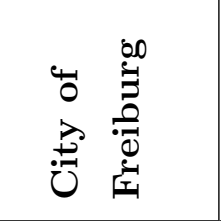 & 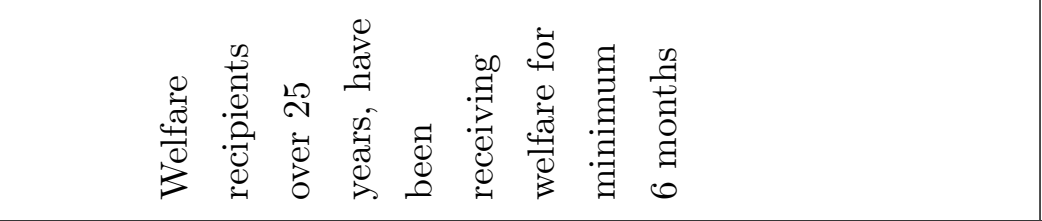 & 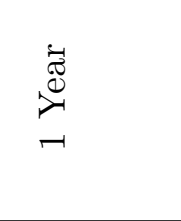 \\
\hline 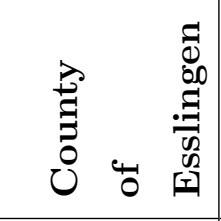 & 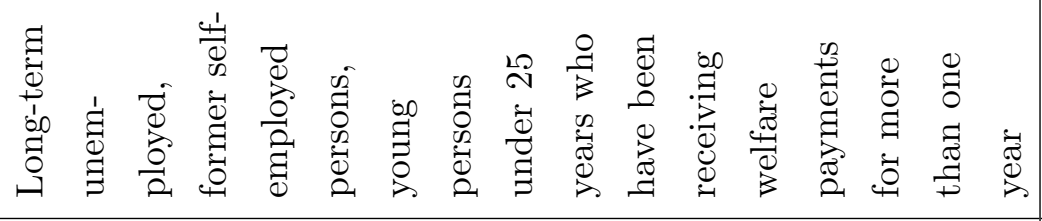 & 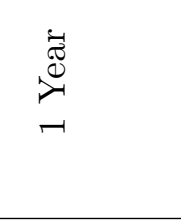 \\
\hline 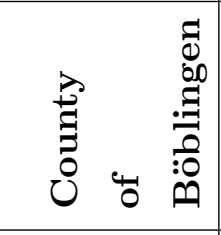 & 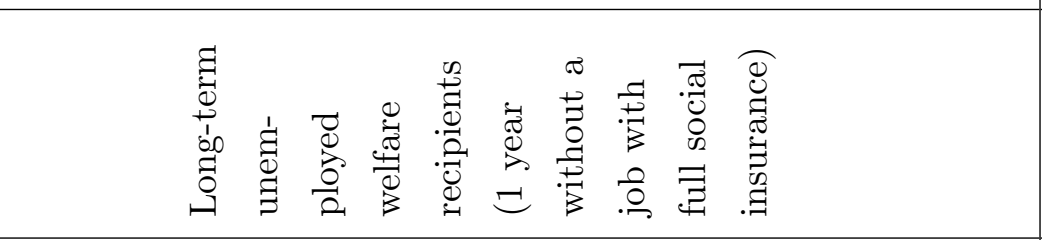 & 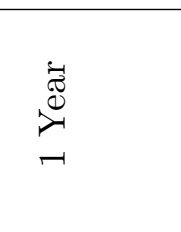 \\
\hline 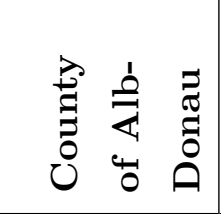 & 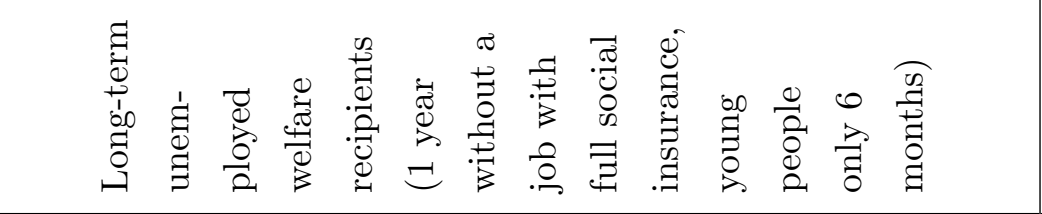 & 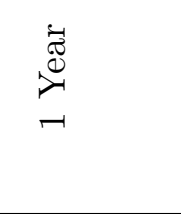 \\
\hline 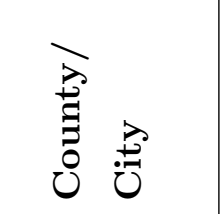 & 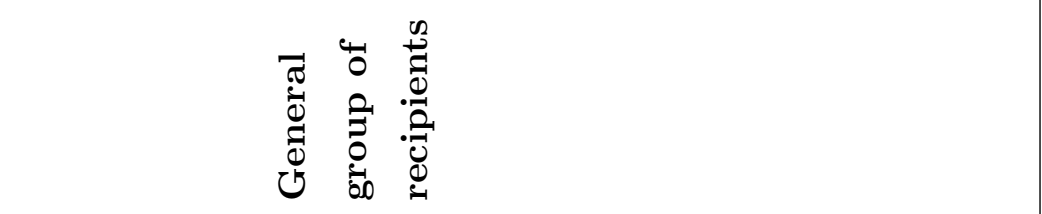 & 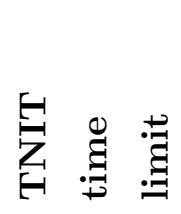 \\
\hline
\end{tabular}




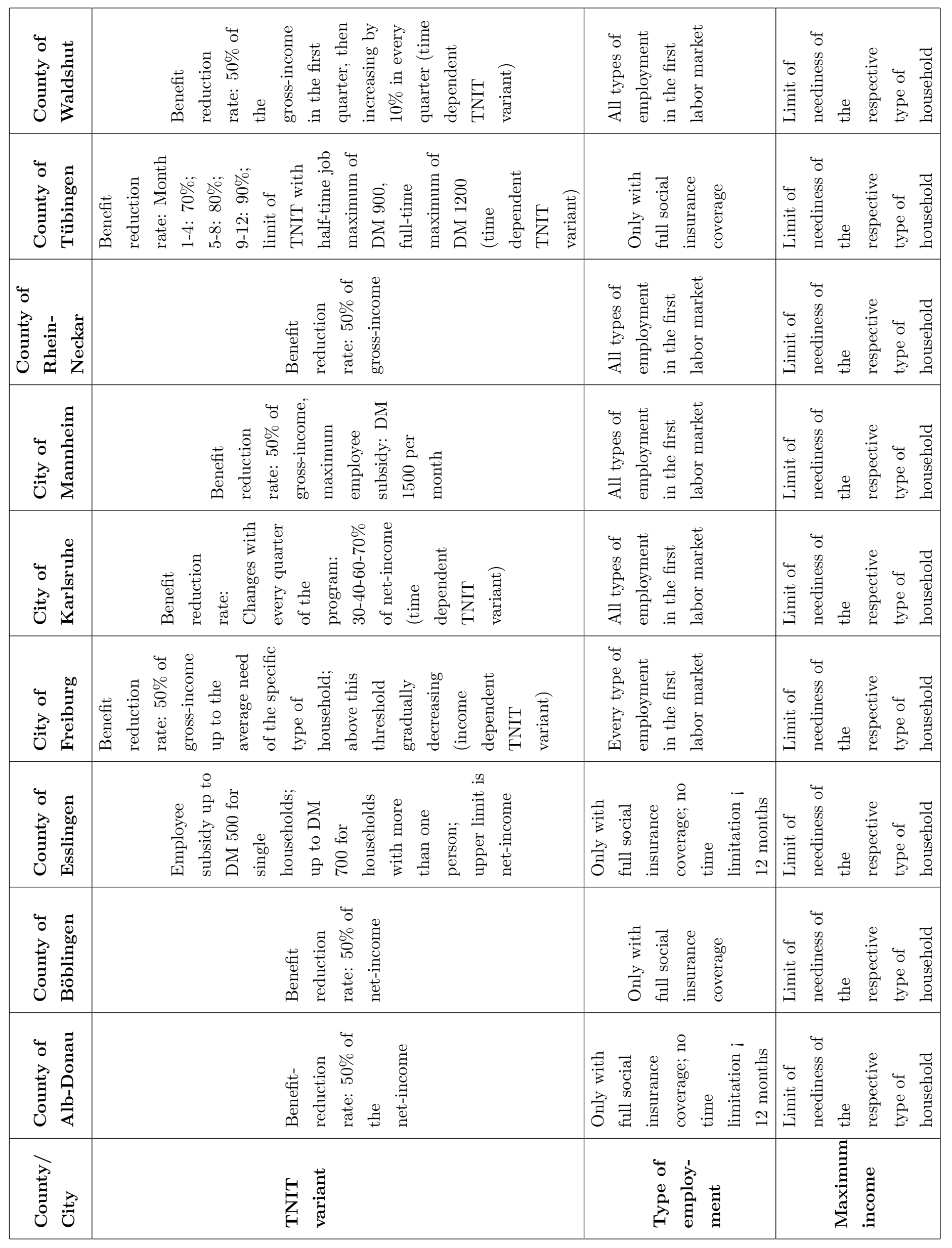




\begin{tabular}{|c|c|c|c|c|c|}
\hline 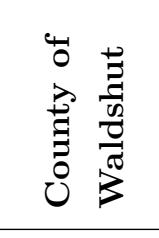 & 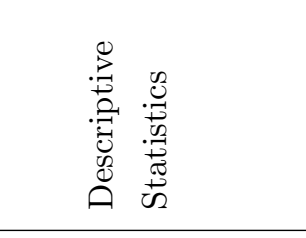 & 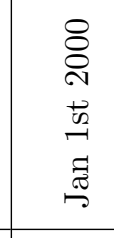 & 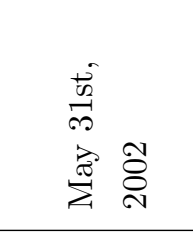 & 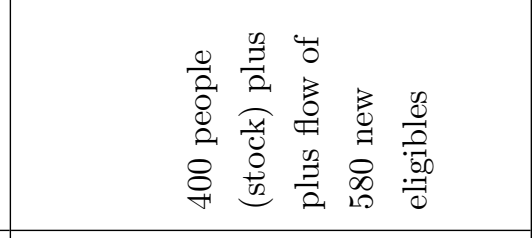 & $\stackrel{\infty}{\infty}$ \\
\hline 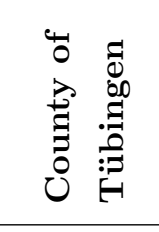 & 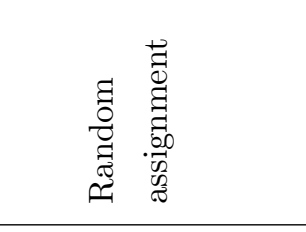 & 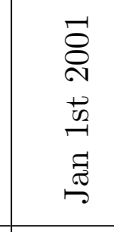 & 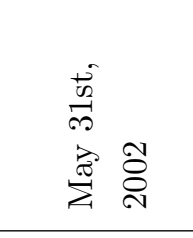 & 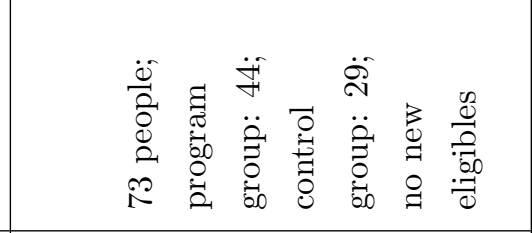 & $\neg$ \\
\hline $\begin{array}{lll} & \\
0\end{array}$ & 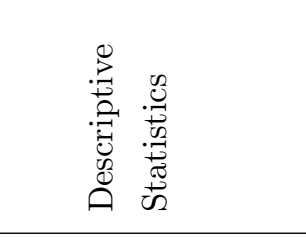 & 点 & 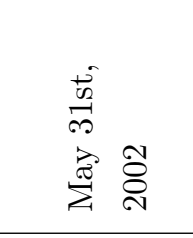 & 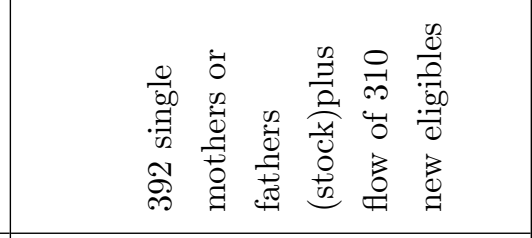 & $\underline{b}$ \\
\hline 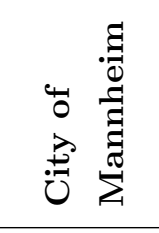 & 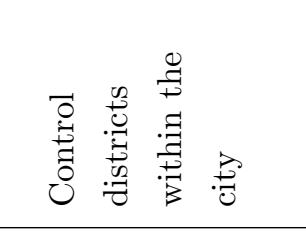 & 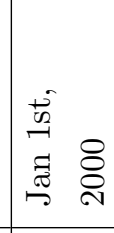 & 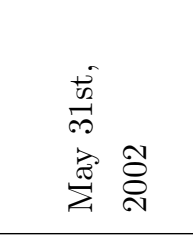 & 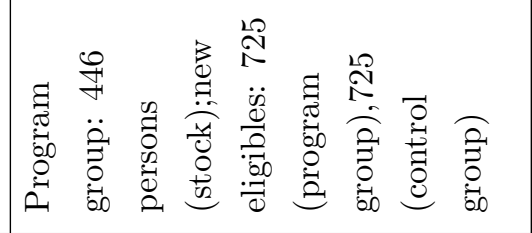 & 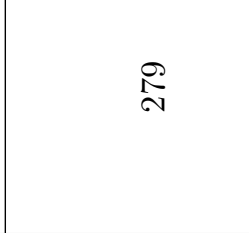 \\
\hline 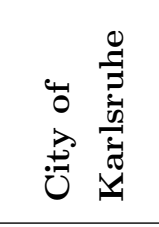 & 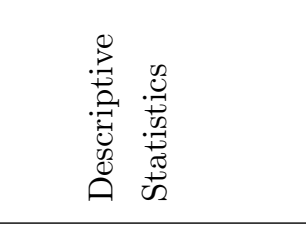 & 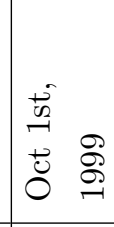 & 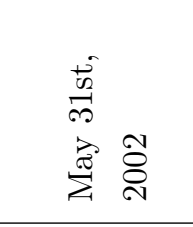 & 离 & $\stackrel{\Re}{g}$ \\
\hline 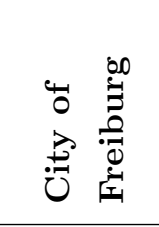 & 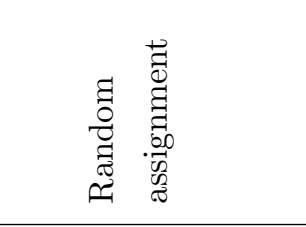 & 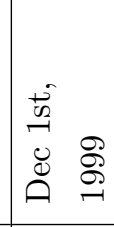 & 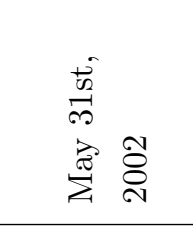 & 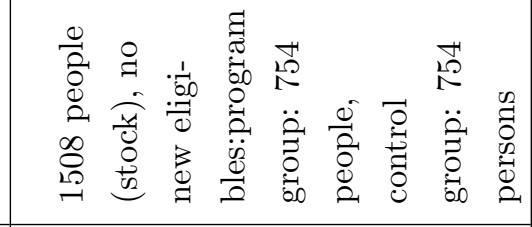 & $\mathscr{m}$ \\
\hline 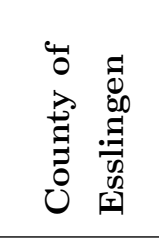 & 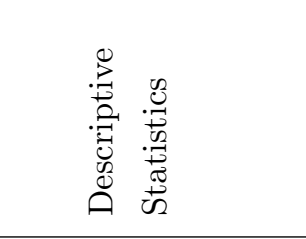 & 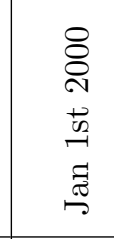 & 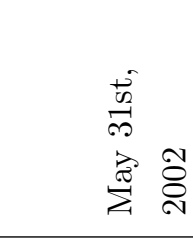 & 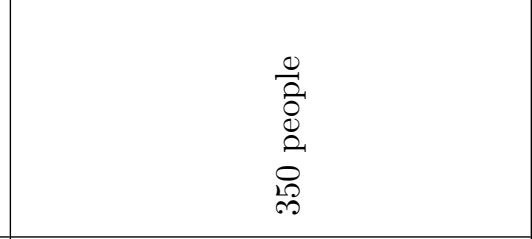 & $\mathscr{8}$ \\
\hline 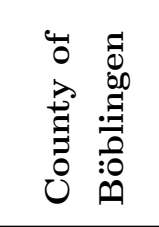 & 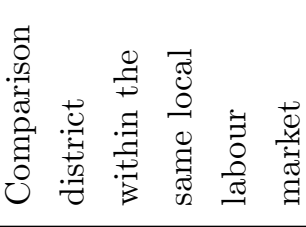 & 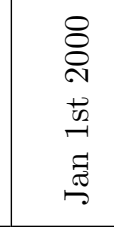 & 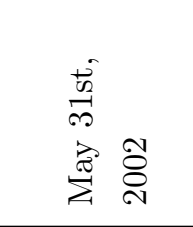 & 惫 & $\mathscr{P}$ \\
\hline 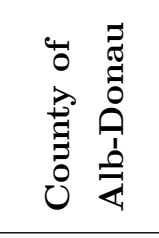 & 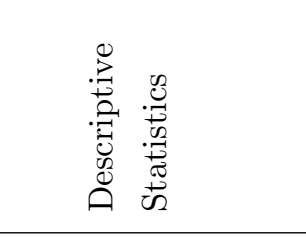 & 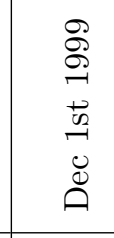 & 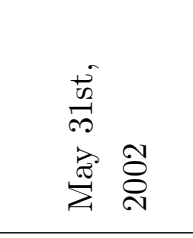 & 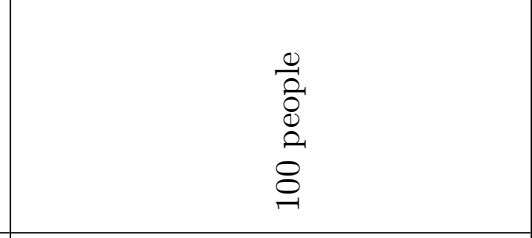 & $\sim$ \\
\hline 居 & 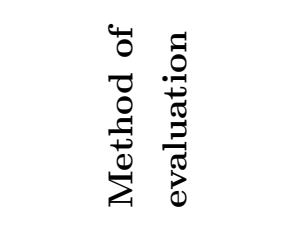 & 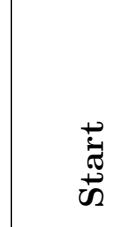 & 蛋 & 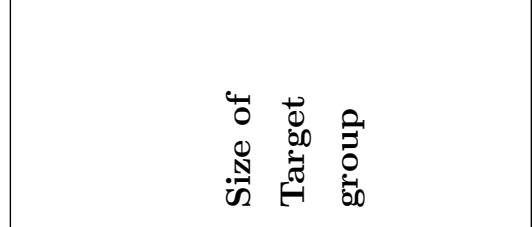 & 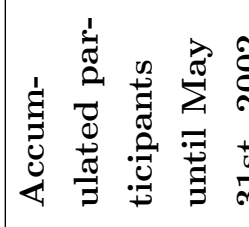 \\
\hline
\end{tabular}




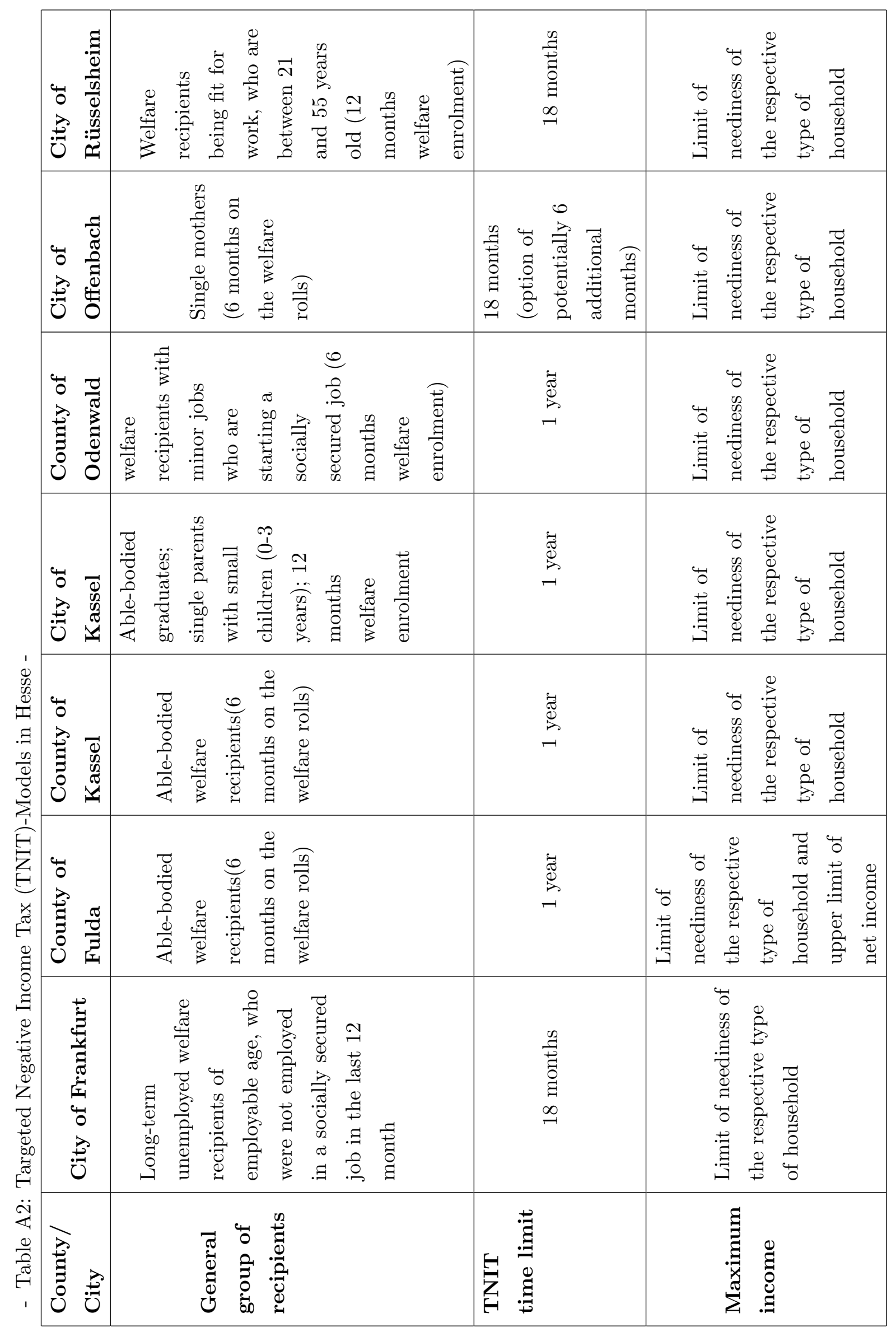




\begin{tabular}{|c|c|c|}
\hline 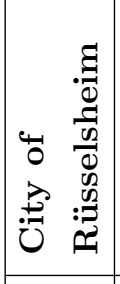 & 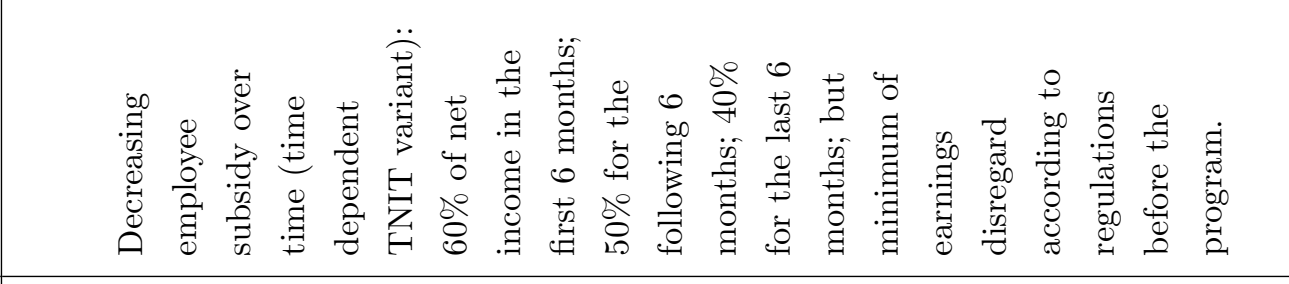 & 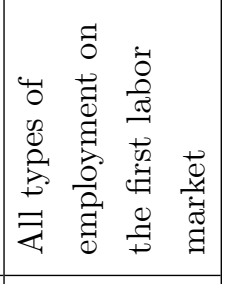 \\
\hline 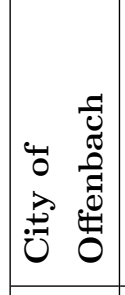 & 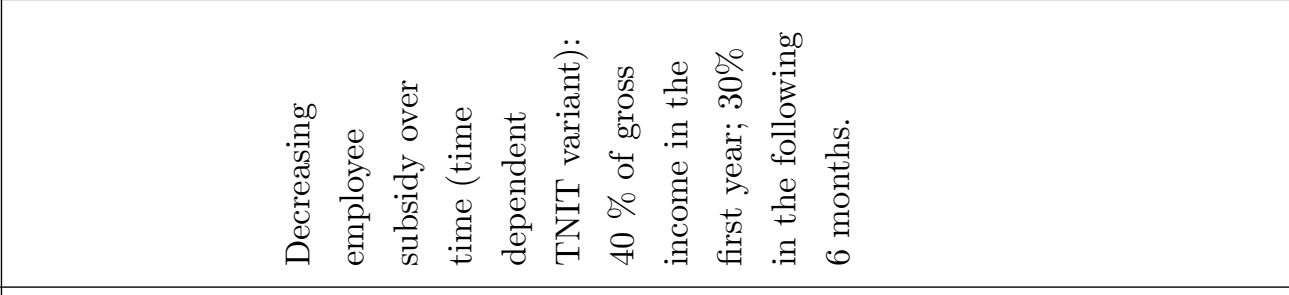 & 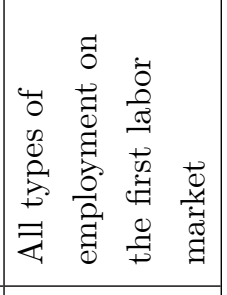 \\
\hline 吾 & 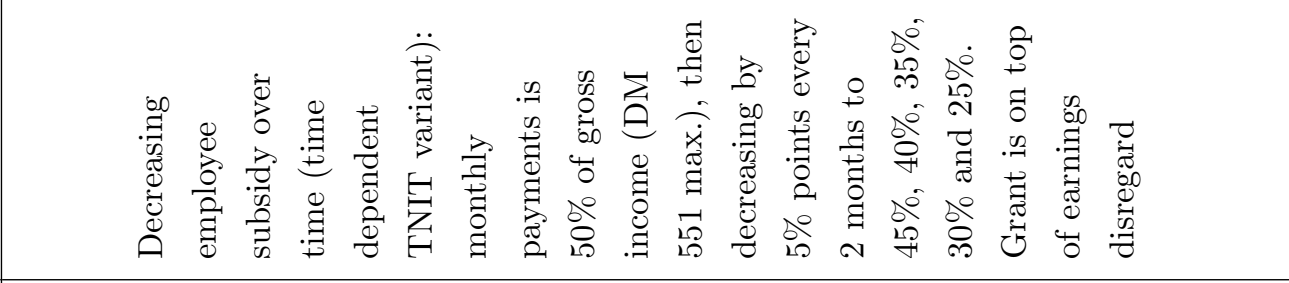 & 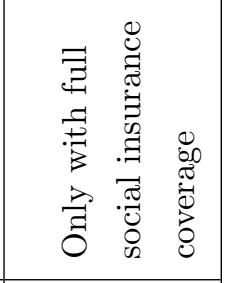 \\
\hline 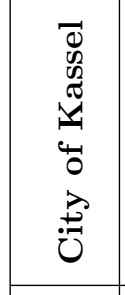 & 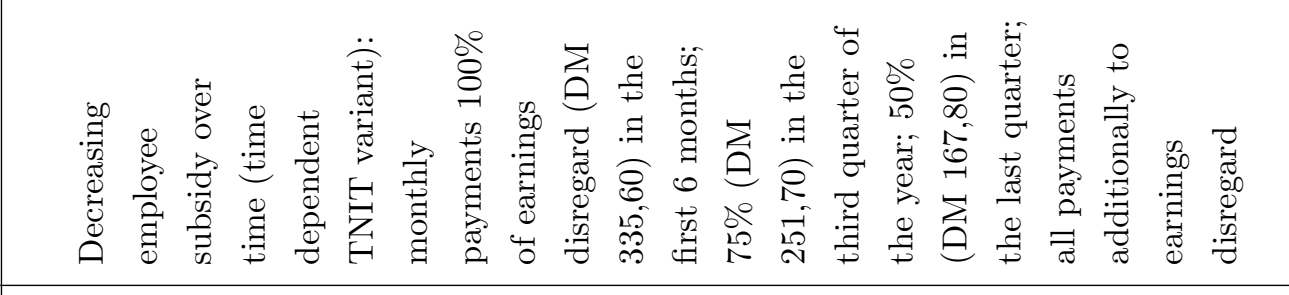 & 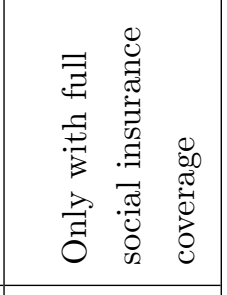 \\
\hline 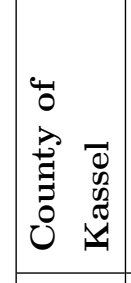 & 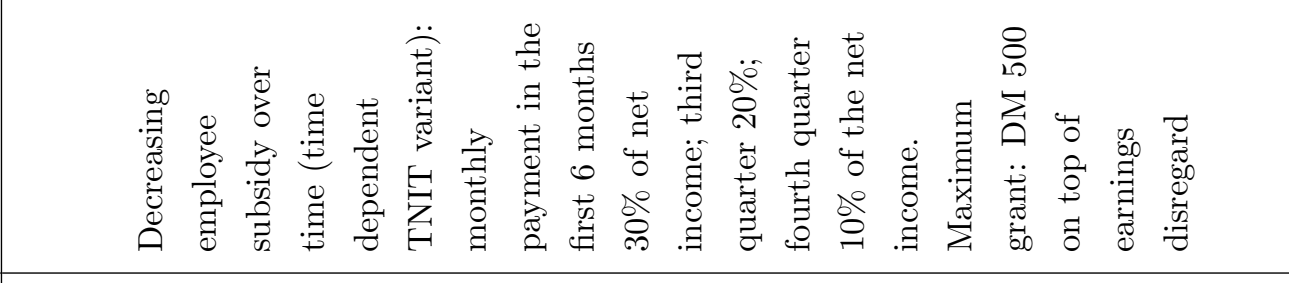 & 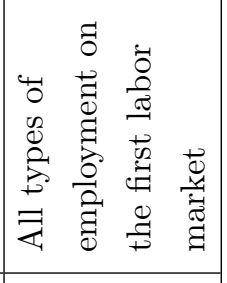 \\
\hline 吾 & 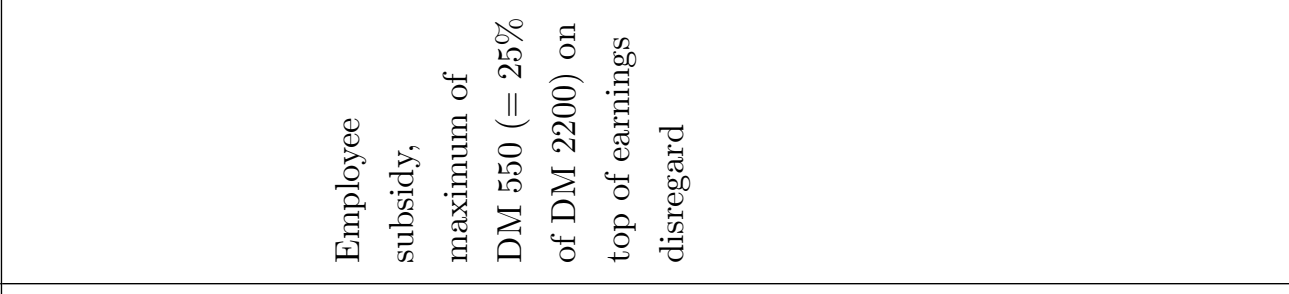 & 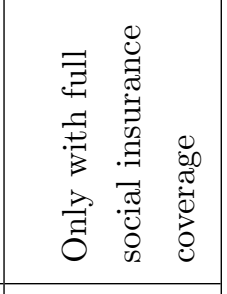 \\
\hline 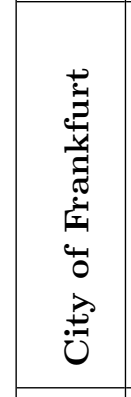 & 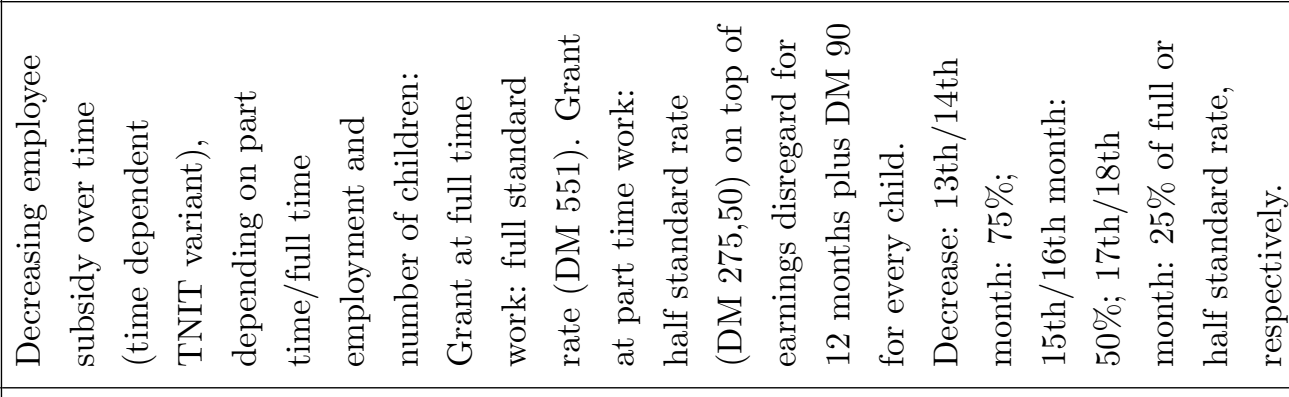 & 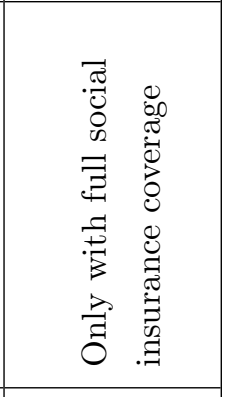 \\
\hline 票 & $\sum_{i}^{E}$ & 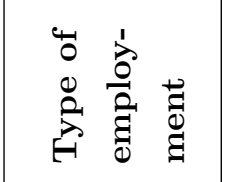 \\
\hline
\end{tabular}




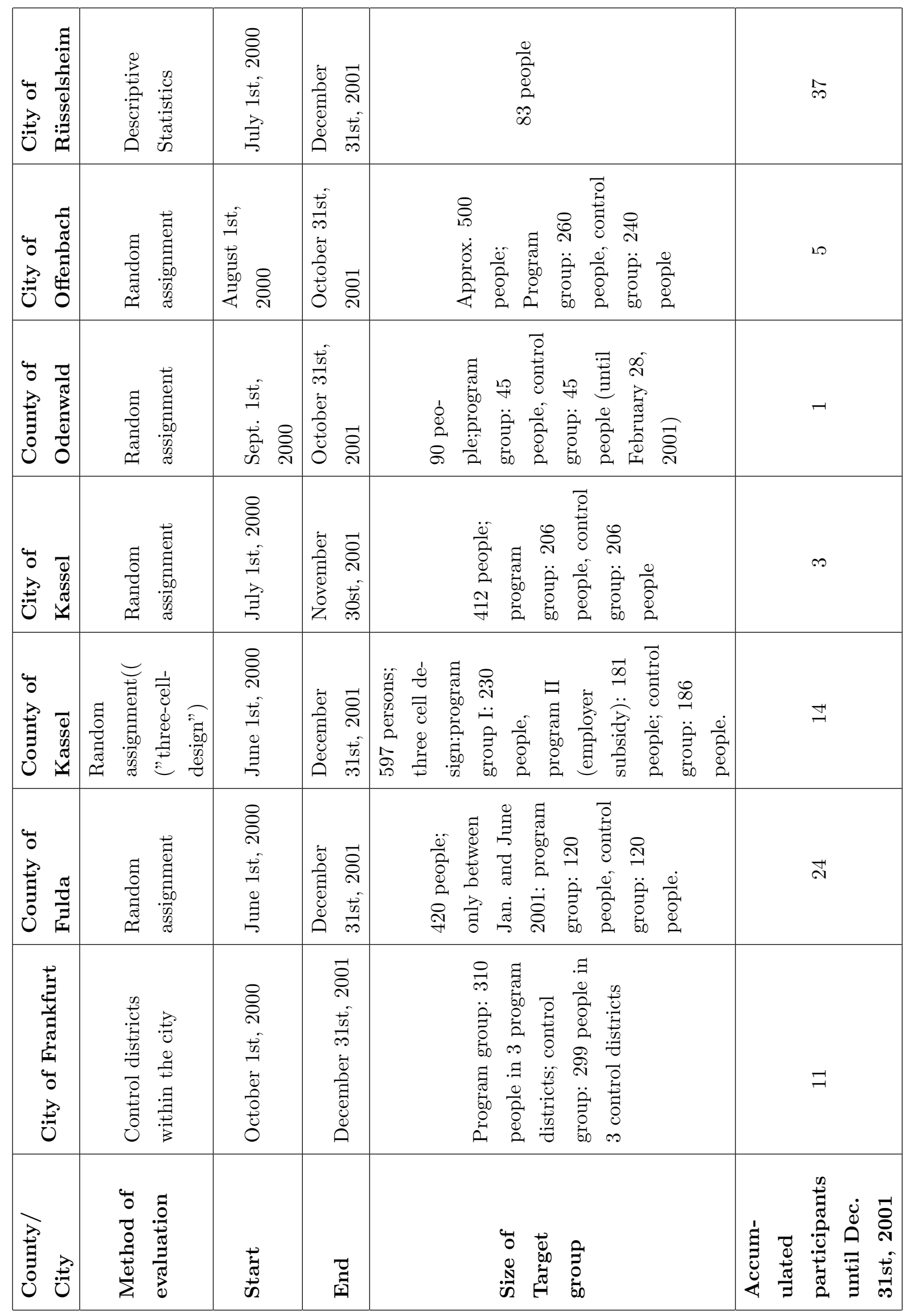


Table A3: Poverty trap and break-even gross income

\begin{tabular}{|c|l|c|c|c|c|}
\hline No & Household type & $\begin{array}{c}\text { Average } \\
\text { monthly } \\
\text { need } \\
\text { standard }\end{array}$ & $\begin{array}{c}\text { Maximal } \\
\text { additional } \\
\text { income }\end{array}$ & $\begin{array}{c}\text { Maximal } \\
\text { disposable } \\
\text { income }\end{array}$ & $\begin{array}{c}\text { Break-even } \\
\text { gross } \\
\text { income }\end{array}$ \\
\hline I & single people & 1100 & 274 & 1374 & 1718 \\
\hline II & single mother with one child & 1850 & 365 & 2215 & 2769 \\
\hline III & single mother with two children & 2450 & 365 & 2815 & 3519 \\
\hline IV & single mother with three or more children & 3700 & 365 & 4065 & 5081 \\
\hline V & couple without children & 1700 & 274 & 1974 & 2468 \\
\hline VI & couple with one child & 2200 & 274 & 2474 & 3093 \\
\hline VII & couple with two children & 2700 & 274 & 2974 & 3718 \\
\hline VIII & couple with three or more children & 3810 & 274 & 4084 & 5105 \\
\hline
\end{tabular}


Table A4: TNIT in Comparison with the Status Quo - City of Mannheim, Household Type Single person

\begin{tabular}{|c|c|c|c|c|c|}
\hline $\begin{array}{c}\text { Average } \\
\text { monthly } \\
\text { need } \\
\text { standard }\end{array}$ & $\begin{array}{c}\text { Monthly } \\
\text { gross } \\
\text { income }\end{array}$ & $\begin{array}{c}\text { Monthly } \\
\text { net } \\
\text { income }\end{array}$ & $\begin{array}{c}\text { Monthly } \\
\text { disposable } \\
\text { income at } \\
\text { status quo }\end{array}$ & $\begin{array}{c}\text { Monthly } \\
\text { disposable } \\
\text { income with } \\
\text { TNIT }\end{array}$ & $\begin{array}{c}\text { Earnings } \\
\text { Supplement } \\
\text { (TNIT) }\end{array}$ \\
\hline 1100 & 100 & 100 & 1200 & 1200 & - \\
\hline 1100 & 141 & 141 & 1241 & 1241 & - \\
\hline 1100 & 200 & 200 & 1250 & 1250 & - \\
\hline 1100 & 300 & 300 & 1265 & 1265 & - \\
\hline 1100 & 400 & 400 & 1280 & 1300 & 20 \\
\hline 1100 & 500 & 500 & 1295 & 1350 & 55 \\
\hline 1100 & 600 & 600 & 1310 & 1400 & 90 \\
\hline 1100 & 700 & 560 & 1303 & 1450 & 147 \\
\hline 1100 & 800 & 640 & 1315 & 1500 & 185 \\
\hline 1100 & 900 & 720 & 1327 & 1550 & 223 \\
\hline 1100 & 1000 & 800 & 1339 & 1600 & 261 \\
\hline 1100 & 1100 & 860 & 1348 & 1650 & 302 \\
\hline 1100 & 1200 & 956 & 1360 & 1700 & 340 \\
\hline 1100 & 1300 & 1035 & 1372 & 1750 & 378 \\
\hline 1100 & 1400 & 1115 & 1374 & 1800 & 426 \\
\hline 1100 & 1500 & 1195 & 1374 & 1850 & 476 \\
\hline 1100 & 1600 & 1270 & 1374 & 1900 & 526 \\
\hline 1100 & 1700 & 1328 & 1374 & 1950 & 576 \\
\hline 1100 & 1800 & 1387 & 1387 & 2000 & 613 \\
\hline 1100 & 1900 & 1442 & 1442 & 2050 & 608 \\
\hline 1100 & 2000 & 1500 & 1500 & 2100 & 600 \\
\hline 1100 & 2100 & 1552 & 1552 & 2150 & 598 \\
\hline 1100 & 2200 & 1602 & 1602 & 2200 & 598 \\
\hline 1100 & 2300 & 1649 & 1649 & 2250 & 601 \\
\hline 1100 & 2400 & 1695 & 1695 & 2300 & 605 \\
\hline 1100 & 2500 & 1741 & 1741 & 2350 & 609 \\
\hline 1100 & 2600 & 1788 & 1788 & 2400 & 612 \\
\hline 1100 & 2700 & 1833 & 1833 & 2450 & 617 \\
\hline 1100 & 2800 & 1873 & 1873 & 2500 & 627 \\
\hline
\end{tabular}




\begin{tabular}{|l|l|l|l|l|l|}
\hline 1100 & 2900 & 1916 & 1916 & 2550 & 634 \\
\hline 1100 & 3000 & 1957 & 1957 & 2600 & 643 \\
\hline 1100 & 3100 & 1999 & 1999 & 2600 & 601 \\
\hline 1100 & 3200 & 2042 & 2042 & 2600 & 558 \\
\hline 1100 & 3300 & 2088 & 2088 & 2600 & 512 \\
\hline 1100 & 3400 & 2134 & 2134 & 2600 & 466 \\
\hline 1100 & 3500 & 2179 & 2179 & 2600 & 421 \\
\hline 1100 & 3600 & 2224 & 2224 & 2600 & 376 \\
\hline 1100 & 3700 & 2268 & 2268 & 2600 & 332 \\
\hline 1100 & 3800 & 2312 & 2312 & 2600 & 288 \\
\hline 1100 & 3900 & 2357 & 2357 & 2600 & 243 \\
\hline 1100 & 4000 & 2401 & 2401 & 2600 & 199 \\
\hline 1100 & 4100 & 2443 & 2443 & 2600 & 157 \\
\hline 1100 & 4200 & 2487 & 2487 & 2600 & 113 \\
\hline 1100 & 4300 & 2530 & 2530 & 2600 & 70 \\
\hline 1100 & 4400 & 2573 & 2573 & 2600 & 27 \\
\hline 1100 & 4500 & 2616 & 2616 & 2600 & \\
\hline
\end{tabular}

